\title{
SHARE AND SHARE ALIKE: UNDERSTANDING AND ENFORCING OPEN SOURCE AND FREE SOFTWARE LICENSES
}

\author{
By Brian W. Carver
}

On September 27, 1983, Richard M. Stallman began a software revolution with a post to the Usenet newsgroup, ${ }^{1}$ net.unix-wizards. ${ }^{2} \mathrm{He}$ announced his plan to write a complete software system called GNU that would be compatible with the UNIX computer operating systems in wide use at the time. ${ }^{3}$ At the time, Stallman could not have known that the engine of his revolution was not going to be the free software that he and others would write, but a free software license that he would develop to implement his vision, the GNU General Public License (GPL). ${ }^{4}$

This Note describes the history and the commonly used software licensing terms of the free software and open source movements in Parts I and II, respectively. Next, the Note explains the GPL in Part III. Part IV discusses the recent attempts to enforce the GPL. The GPL is a revolu-

(C) 2005 Brian W. Carver

Verbatim copying and distribution of this entire note is permitted without royalty in any medium, provided this notice is preserved: "This note first published by the Regents of the University of California in the Berkeley Technology Law Journal's Annual Review of Law and Technology."

1. Usenet is one of the oldest computer network communications systems still in wide use. Users read and post email-like messages, called articles, to a number of distributed newsgroups. However, whereas email may be used for one-to-one communication, Usenet is a one-to-many medium. See Usenet, WIKIPEDIA: THE FREE ENCYCLOPEDIA, at http://en.wikipedia.org/wiki/Usenet (last modified Feb. 6, 2005).

2. Initial Announcement, at http://www.gnu.org/gnu/initial-announcement.html (last visited Mar. 6, 2005) (posting from Richard M. Stallman, Programmer, MIT Artificial Intelligence Lab, to net.unix-wizards (Sept. 27, 1983)) [hereinafter net.unix-wizard Announcement].

3. Id.; see David Bennahum, Interview with Richard Stallman, MEME 2.04 (1996), at http:/hammer.prohosting.com/ runlinux/stallman.shtml. UNIX systems are portable, multi-task, and multi-user computer operating systems. On the wide use of UNIX systems at the time, see Marshall Kirk McKusick, Twenty Years of Berkeley Unix: From AT\&T Owned to Freely Redistributable, in OPEN SOURCES: VOICES FROM THE OPEN SOURCE REVOlution 31, 36-39 (Chris DiBona et al. eds., 1999) [hereinafter OPEN SOURCES], available at http://www.oreilly.com/catalog/opensources/book/kirkmck.html.

4. References herein to the GNU General Public License (GPL) will refer to version 2 of that license unless otherwise indicated. GNU General Public License, at http://www.fsf.org/licensing/licenses/gpl.html (last visited Feb. 16, 2005) [hereinafter GNU GPL]. 
tionary copyright license that has allowed software developers to use existing law to copyright their work, while allowing licensees the freedoms to use, copy, modify, and distribute their work, but not to turn the work into a proprietary derivative. This year brought two notable efforts to enforce the license in court. A district court in Munich, Germany has declared the GPL valid and enforceable. Meanwhile, ongoing litigation between The SCO Group (SCO) and International Business Machines (IBM) may clarify how U.S. courts will interpret the GPL.

\section{HISTORICAL BACKGROUND OF THE FREE SOFTWARE AND OPEN SOURCE MOVEMENTS}

\section{A. Richard Stallman and the Free Software Foundation}

The free software movement traces its beginning to a jammed printer. ${ }^{5}$ In the 1970 s, while Richard Stallman was working as a programmer at MIT's Artificial Intelligence (AI) lab, ${ }^{6}$ the environment surrounding software development was quite different from today. ${ }^{7}$ Prior to the appearance of the personal computer in the $1980 \mathrm{~s}$, large mainframes with dumb terminals were the norm. ${ }^{8}$ In this hardware-driven world, software was an afterthought and was often provided with human-readable source code ${ }^{9}$ at no

5. See SAM Williams, Free as IN FreEdom: Richard Stallman's CRUSAde For FREE SOFTWARE 1-12 (2002), available at http://www.oreilly.com/openbook/freedom.

6. While what follows traces the thread of the free software community beginning with Stallman, another segment of the free software community traces its roots to the work done on the Berkeley Software Distribution (BSD), which was an important early UNIX system. That story is ably told by McKusick, supra note 3, at 31-46. Today BSD development continues under a free software license of the same name, the Modified BSD license, primarily through the efforts of the FreeBSD, NetBSD, and OpenBSD projects.

7. See generally Steven Levy, Hackers: Heroes of THE COMPUTER RevoluTION (Updated ed. 2001).

8. For an account of working with some of the earliest computers, such as the UNIVAC and UNIVAC II, see DAVID E. LUNDSTROM, A FEW GOOD MEN FROM UNIVAC (1987). A "dumb" terminal is merely a display and keyboard with little or no independent processing ability that allows one to connect to a remote server or mainframe.

9. WILliaMS, supra note 5, at 1-12; Ira V. Heffan, Note, Copyleft: Licensing Collaborative Works in the Digital Age, 49 StAN. L. REV. 1487, 1492-93 (1997). A binary is an executable file read by the computer. The source code, in contrast, is human-readable, and the normal means by which developers interact with software. 
additional cost, with the purchase of the machines. Software was rarely sold separately. ${ }^{10}$

In this environment, Stallman was free to solve a problem the lab faced with sharing a centralized printer-paper jams. With access to the printer's source code, Stallman was able to improvise a solution by modifying the printer software to send everyone a message any time the printer jammed. Anyone who was hoping to receive a printout would then know to go fix the problem. ${ }^{11}$

However, the AI lab received a new Xerox printer that did not include the source code, so Stallman could not implement a similar fix without that source code. When Stallman visited a professor whom he knew had worked on the printer in question, he requested the source code. But the professor could not give it to Stallman because the professor had signed a nondisclosure agreement with Xerox. ${ }^{12}$

Stallman was stunned. While not the first time Stallman had encountered proprietary software, he marks it as a turning point. ${ }^{13}$ Stallman embraced the culture of sharing that had developed around software. ${ }^{14}$ From his perspective, it was a sharing with no losers, because the digital nature of software enables one to share perfect copies without relinquishing the original. ${ }^{15}$ Hence, to the extent the law allows, you ought always to share software. ${ }^{16}$ To do otherwise, according to Stallman, was unethical and a violation of "the golden rule."17

10. WILLIAMS, supra note 5, at 4. For another helpful history of this period, see Eric S. Raymond, A Brief History of Hackerdom, in OPEN SOURCES, supra note 3, at 19-30, available at $\mathrm{http}: / / \mathrm{www}$.oreilly.com/catalog/opensources/book/raymond.html.

11. WILLIAMS, supra note 5, at 1-5.

12. Id. at 4-9.

13. Id. at 10. In free software and open source circles, "proprietary software" means something closer to "software for which no access to the source code is provided." It does not mean what many attorneys might first assume, namely, "owned software" or "copyrighted software" for, as discussed later, free software is also owned and copyrighted. See Jonathan Zittrain, Normative Principles for Evaluating Free and Proprietary Software, 71 U. CHI. L. REV. 265, 271 (2004) ("Releasing the object code without the source code has been a hallmark of proprietary software, complementing the creator's exercise of a legal right to prevent the use of source code in new works with a technical barrier to unauthorized use.").

14. WilliaMs, supra note 5 , at 5,12 .

15. Id. at 5 .

16. Id. Stallman does not advocate breaking the copyright laws to share software. Rather, he has used copyright law through the GPL to achieve the goal of the widespread sharing of software.

17. Id. at 12. Stallman wrote: 
Stallman recognized a trend that was changing software culture. ${ }^{18}$ Fellow programmers were joining companies that were asking them to sign nondisclosure agreements. ${ }^{19}$ Stallman's solution was to create a computing environment, an operating system, where he could guarantee that the source code would always be available. ${ }^{20}$ At that time, UNIX systems were the standard and so Stallman wanted to write a compatible operating system. ${ }^{21}$ He called it "GNU" (pronounced guh-noo), a recursive acronym for GNU's Not UNIX."

Stallman was concerned that his employer might try to claim the work he did on his new GNU system, so he quit his job to guarantee himself control over his code. ${ }^{23} \mathrm{He}$ soon founded the Free Software Foundation (FSF), ${ }^{24}$ now a world-wide organization advocating the freedoms Stallman believes all software users should have. ${ }^{25}$ While working on the GNU system, Stallman experimented with different copyright licenses, each designed to maximize sharing of and access to the source code. ${ }^{26}$ By February 1989, these licenses had evolved into the first version of the GNU General Public License. ${ }^{27}$

I consider that the golden rule requires that if I like a program I must share it with other people who like it. I cannot in good conscience sign a nondisclosure agreement or a software license agreement.

So that I can continue to use computers without violating my principles, I have decided to put together a sufficient body of free software so that I will be able to get along without any software that is not free.

net.unix-wizards Announcement, supra note 2.

18. Id.

19. Id. at 11; Richard Stallman, The GNU Operating System and the Free Software Movement, in OPEN SOURCES, supra note 3, at 53, 53-56, available at http://www. oreilly.com/catalog/opensources/book/stallman.html.

20. net.unix-wizards Announcement, supra note 2.

21. Id.; Bennahum, supra note 3 .

22. The GNU Operating System, at http://www.gnu.org (last updated Feb. 26, 2005); see also The Free Software Foundation, at http://www.fsf.org/index.html (last visited Feb. 16, 2005).

23. WILlIAMS, supra note 5, at 102; Stallman, supra note 19, at 57.

24. WiLliams, supra note 5, at 106; The Free Software Foundation, supra note 22.

25. The Free Software Foundation, supra note 22; Free Software Foundation Europe, Free Software Foundation, at http://www.fsfeurope.org (last visited Feb. 16, 2005); Free Software Foundation of India, Free Software Foundation, at http://www. fsf.org.in (last modified Feb. 9, 2005); Free Software Foundation France, FSF France, at $\mathrm{http}: / /$ www.fsffrance. org (last updated Oct. 22, 2003).

26. WILLIAMS, supra note 5, at 124.

27. Id. at 126 . Version 1 of the GNU GPL, which has since been superseded by Version 2, is available at GNU General Public License Version 1, at http://www.gnu.org/ 


\section{B. The GNU General Public License}

Stallman's work on various GNU programs was critical to the project's continuing development, but it was the unique copyright license he developed that would prove to have the greatest influence on the free software movement. Currently, two of the most prominent online repositories of free software, freshmeat.net and SourceForge.net, have $68 \%$ and $69 \%$ respectively of their software licensed under the GPL. The next most commonly-used free software license only garners between a 6-11\% share. ${ }^{28}$ The features of the GPL that most prominently contributed to its widespread adoption were the license's motivating philosophy of software freedom, the fact that most software available under the license was available at no cost, ${ }^{29}$ and most importantly, that the license's reciprocal nature encouraged further use of the license.

First, the philosophy Stallman outlined, now embodied in the Free Software Definition, appealed to many software developers and users just as the Internet was enabling this disparate group to collaborate across previously insurmountable distances. ${ }^{30}$ Many believed that source code should be available for copying, modification, and subsequent distribution

copyleft/copying-1.0.html (last modified Feb. 12, 2001). There are other "General Public Licenses" such as the Affero GPL. Affero General Public License, at http://www.affero. org/oagpl.html (last visited Feb. 16, 2005). To avoid confusion, reference to the "GPL" will mean the GNU GPL Version 2. For further information on the GPL and especially on other licenses, see ROD DIXON, OPEN SOURCE SOFTWARE LAW (2003); LAWRENCE Rosen, Open SOURCe Licensing: SoftWare Freedom and INTEllectual Property LaW (2004); ANDrew M. St. LaURent, Understanding Open SOURCE and Free SOFTWARE LICENSING, (2004), available at http://www.oreilly.com/catalog/osfreesoft/ book.

28. As of February 2005 , over $68 \%$ of the projects at freshmeat.net were licensed under the GPL. See freshmeat.net: Statistics and Top 20, at http://freshmeat.net/stats (last visited Mar. 17, 2005). At SourceForge.net, of projects having OSI-approved licenses, over $69 \%$ were GPL. See SourceForge.net: Software Map, at http://sourceforge.net/soft waremap/trove_list.php?form_cat=13 (last visited Feb.8, 2005) (showing 59,837 projects under OSI-approved licenses as of Feb. 8, 2005), and at http://sourceforge.net/softwaremap/trove_list.php?form_cat=14 (last visited Feb. 8) (showing 41,445 projects licensed under the GPL and 6,670 under the LGPL as of Feb. 8, 2005). OSI is the Open Source Initiative that will be discussed below in Part I C. The next most commonly-used license, after the GPL, at freshmeat.net was the GNU Lesser General Public License (LGPL) at under $6 \%$. See freshmeat.net, supra. At SourceForge.net, of projects having OSIapproved licenses, the LGPL was the next most-used license, after the GPL, and the LGPL constituted just over 11\%. See SourceForge.net, supra.

29. It is critical to distinguish between "free" in the sense of "freedom" and "free" in the sense of "no cost." Free software, to be free software, must be free in the former sense, but is often not free in the latter sense. See Stallman, supra note 19, at 56-57.

30. Id. at 56,60 . 
in order to facilitate innovation and improvements with and within the software. ${ }^{31}$ Second, software licensed under the GPL was usually provided at no cost or at a very low cost to cover the expense of the transfer. ${ }^{32}$ Not surprisingly, quality software available at no cost attracted significant attention. Finally, the minimal barriers to acquiring and modifying the software generated their intended effect: improved versions of the software, which in turn attracted more users and developers. ${ }^{33}$ The GPL's requirement that any distributed modifications must themselves be licensed under the GPL also helped to perpetuate both the license and the underlying software. $^{34}$ This self-perpetuating feature of the GPL is its most unique feature and is likely primarily responsible for its widespread adoption.

\section{The Open Source Initiative}

While Stallman started a social movement based upon an ethical conviction, others found that providing source code to users and developers had other more practical advantages. ${ }^{35}$ In January 1998, Netscape announced its decision to release the source code to its web browser, Navigator. ${ }^{36}$ The binary form of Netscape's browser had been available for download, at no cost for non-commercial uses, since its inception in 1994, but the underlying source code had never been so provided. ${ }^{37}$ The promise of browser-based applications had led to "the browser wars" and by 1998

31. See SteVEn Weber, THE SuCCESS OF OPEN SOURCE 116 (2004), stating that: This is not to say that creating the open source definition signed away anyone's belief in or commitment to the underlying 'good' of the process. Many developers believe as strongly as ever that their values around cooperation and sharing in knowledge production are the fundamental reasons why they do what they do.

32. Stallman notes that he used to charge $\$ 150$ for a copy of his EMACS software as a way to support himself, but he encouraged those who received such copies to share their copies with others. See Stallman, supra note 19, at 58.

33. Id. at 62,66 .

34. The GPL also requires that a copy (digital or otherwise) of the license's text itself be included with any software distributed under the GPL. GNU GPL, supra note 4, at Section 1. While the stated purpose of this requirement is to inform users of their rights and responsibilities regarding the software, it also serves to perpetuate knowledge of the GPL itself.

35. This is best summarized in ERIC RAYMOND, THE CATHEDRAL AND THE BAZAAR: Musings ON LINUX AND OPEN SOURCE BY AN ACCIDENTAL RevolutionaRY (1999), available at $\mathrm{http}: / / \mathrm{www}$.catb.org/ esr/writings/cathedral-bazaar/cathedral-bazaar.

36. For one version of this story, see Jim Hamerly et al., Freeing the Source: The Story of Mozilla, in OPEN SOURCES, supra note 3, at 197-206, available at http://www. oreilly.com/catalog/opensources/book/netrev.html.

37. See Browser Wars, WIKIPEDIA: THE FREE ENCYCLOPEDIA, at http://en.wiki pedia.org/wiki/Browser_wars (last modified Feb. 3, 2005). 
Microsoft's Internet Explorer web browser had surpassed Navigator's market share. ${ }^{38}$ Netscape's announcement cited as the rationale for releasing the source code the ability "to harness the creative power of thousands of programmers on the Internet by incorporating their best enhancements into future versions" of Netscape's software. ${ }^{39}$

Hoping to capitalize on Netscape's move, a group of free software developers and advocates met to address a perceived problem with the free software label. ${ }^{40}$ They believed that businesses were not embracing the term or the philosophy because of the word free. While Stallman and the FSF explained that they meant free as in freedom; it also inevitably suggested free as in no cost. ${ }^{41}$ Businesses and investors rarely understood the intended meaning and wrongly assumed that all free software had to be provided at no cost. ${ }^{42}$

One of the meeting's attendees, Eric Raymond, had popularized the practical benefits of Linus Torvalds' development process for the Linux kernel and of the free software development process generally. ${ }^{43}$ Raymond

38. Id.

39. See Press Release, Netscape Communications Corp., Netscape Announces Plans to Make Next-Generation Communicator Source Code Available Free on the Net (Jan. 22, 1998), at http://wp.netscape.com/newsref/pr/newsrelease558.html.

40. History of the OSI, Open Source Initiative, at http://www.opensource.org/docs/ history.php (last visited Mar. 6, 2005) ("The people present included Todd Anderson, Chris[tine] Peterson (of the Foresight Institute), John "maddog" Hall and Larry Augustin (both of Linux International), Sam Ockman (of the Silicon Valley Linux User's Group), and Eric Raymond.").

41. Stallman has famously quipped, "To understand the concept, you should think of 'free' as in 'free speech,' not as in 'free beer.'" The Free Software Definition, Free Software Foundation, at http://www.fsf.org/licensing/essays/free-sw.html (last modified Feb. 12, 2005).

42. On the contrary, the GPL itself speaks of when you "distribute copies of such a program, whether gratis or for a fee." GNU GPL, supra note 4, at Preamble; and says "You may charge a fee for the physical act of transferring a copy, and you may at your option offer warranty protection in exchange for a fee." Id. at Section 1. License fees are more complicated. Frequently Asked Questions About the GNU GPL, at http://www.fsf. org/licensing/licenses/gpl-faq.html\#TOCDoesTheGPLRequireAvailabilityToPublic (last visited Feb. 16, 2005), explains that you could technically charge a licensing fee, but "if someone pays your fee and gets a copy, the GPL gives them the freedom to release it to the public, with or without a fee. For example, someone could pay your fee, and then put her copy on a web site for the general public." Consequently, software under the GPL is often not a source of recurring licensing fees. More likely, and allowed, are fees for distribution, service, warranty protection, and indemnification.

43. See RAYMOND, supra note 35. A "kernel" is the core of an operating system that controls the accessing of the hardware by other programs. See Kernel (computer science), WIKIPEDIA: THE FREE ENCYCLOPEDIA at http://en.wikipedia.org/wiki/Kernel_ (computer_science) (last modified Feb. 14, 2005). The Linux kernel can be added to the 
noted the benefits of a collaborative environment involving freely available source code, including the ability to find and fix bugs more quickly. ${ }^{44}$ Raymond and others saw that Netscape was going to release its source code for these same pragmatic business reasons, and indeed Netscape informed Raymond that his views had been influential in its decision. ${ }^{45}$ To encourage other businesses to see these advantages, a new label for such software was sought. ${ }^{46}$ The term "open source" was suggested and adopted, as well as an Open Source Definition, written by Bruce Perens, which defines what counts as open source software. ${ }^{47}$ The Open Source Initiative (OSI), a California public benefit corporation, was founded to oversee the definition and to promote understanding of the various open source licenses. ${ }^{48}$ The adoption of the phrase "open source". has been extremely effective. ${ }^{49}$

\section{UNDERSTANDING OPEN SOURCE AND FREE SOFTWARE LICENSES}

\section{A. Comparing the Free Software Definition and the Open Source Definition}

Richard Stallman and the FSF have taken a stand against the "open source" label because in their view it minimizes the most important part of the concept: the user's freedom. ${ }^{50}$ Consequently, what the FSF considers a "free software" license is based on the Free Software Definition," while what the OSI considers an "open source" license is based on the Open Source Definition. ${ }^{52}$

GNU tools developed by Stallman's GNU Project, along with other free software, to create a complete free software operating system, called GNU/Linux. For more on Torvalds and the development of the Linux kernel, see LINUS TORVALDS \& DAVID DIAMOND, JUST FOR FUN: THE STORY OF AN ACCIDENTAL REVOLUTIONARY (2001).

44. RAYMOND, supra note 35.

45. Id. at 61-63.

46. History of the OSI, supra note 40.

47. See id.; Bruce Perens, The Open Source Definition, in OPEN SoURCES, supra note 3, at 171-188, available at http://www.oreilly.com/catalog/opensources/book/ perens.html; The Open Source Definition, Open Source Initiative, at http://www.open source.org/docs/definition.php (last visited Feb. 16, 2005).

48. History of the OSI, supra note 40.

49. See, e.g., Eric Raymond, A Fan of Freedom: Thoughts on the Biography of RMS (Nov. 11, 2003), at http://www.catb.org/ esr/writings/rms-bio.html.

50. Why "Free Software" Is Better Than "Open Source", at http://www.gnu.org/ philosophy/free-software-for-freedom.html (last updated Oct: 6, 2004).

51. The Free Software Definition, supra note 41.

52. The Open Source Definition, supra note 47. 
The Free Software Definition is largely comprised of the four freedoms:

0 . The freedom to run the program, for any purpose.

1. The freedom to study how the program works, and adapt it to your needs. Access to the source code is a precondition for this.

2. The freedom to redistribute copies so you can help your neighbor.

3. The freedom to improve the program, and release your improvements to the public, so that the whole community benefits.

Access to the source code is a precondition for this. ${ }^{53}$

In contrast, the Open Source Definition contains ten criteria, requiring, among other things, free redistribution rights, access to source code, permission to modify and distribute modifications, and forbidding discrimination against persons, groups, or fields of endeavor. ${ }^{54}$ The first criterion reads:

\section{Free Redistribution}

The license shall not restrict any party from selling or giving away the software as a component of an aggregate software distribution containing programs from several different sources. The license shall not require a royalty or other fee for such sale. ${ }^{55}$

This is indicative of the style of the other nine criteria. In general, the Open Source Definition is more detailed than the Free Software Definition

53. The Free Software Definition, supra note 41 . The text following the four freedoms is equally important to predicting what the FSF will consider a free software license.

54. There are several other requirements. See The Open Source Definition, supra note 47. References to the Open Source Definition will mean version 1.9, the most recent incarnation as of this writing. The Open Source Definition was adapted from the Debian Free Software Guidelines, also written by Bruce Perens, mainly by removing references to Debian. See Debian Social Contract, Version 1.0, Debian Project, at http://www. debian.org/social_contract.1.0 (last modified Mar. 3, 2005). "The Debian Project is an association of individuals who have made common cause to create a free operating system. [The] operating system that [they] have created is called Debian GNU/Linux, or simply Debian for short." About Debian, Debian Project, at http://www.debian.org/ intro/about (last modified Mar. 4, 2005). Debian GNU/Linux is one of the most popular and widely-used GNU/Linux distributions and is used as a starting point or basis for many other popular distributions. The readers of Linux Journal magazine have voted Debian GNU/Linux their favorite distribution in both 2003 and 2004. 2004 Reader's Choice Awards, LINUX J., Nov. 2004, at 80 , available at http://www.linuxjournal.com/article/ 7724. Debian-based distributions include KNOPPIX, Libranet, Linspire, MEPIS, Ubuntu, and Xandros. Software Distributions Based on Debian, Debian Project, at http://www. debian.org/misc/children-distros (last modified Mar. 4, 2005).

55. The Open Source Definition, supra note 47. Read carefully, distributing copies of a program for a fee is allowed, but a royalty cannot be required. 
and arguably provides clearer direction to those hoping to write a software license about what features such a license should and should not contain. ${ }^{56}$

Software licensed under the GPL, such as the Linux kernel, satisfies both definitions and hence may accurately be called both "free software" and "open source" software. Indeed, the vast majority of Free Software and Open Source licenses satisfy both definitions, however, this is not always the case. ${ }^{57}$ However, this is not always the case.

56. In defense of the Free Software Definition, the four freedoms are not the entirety of the definition. The FSF provides explanatory text that, while not organized into ten bullet points, provides explanations that give further guidance as to what the four freedoms must entail. See The Free Software Definition, supra note 41.

57. Another license often used in the free software community, the Modified BSD license, also satisfies both the Open Source Definition and the Free Software Definition. See The Approved Licenses, Open Source Initiative, at http://www.opensource.org/ licenses (last visited Mar. 6, 2005); The BSD License (in template form), at Open Source Initiative, http://www.opensource.org/licenses/bsd-license.php (last visited Mar. 6, 2005); Various Licenses and Comments About Them, Free Software Foundation, at http://www. fsf.org/licensing/licenses/license-list.html (last modified Feb. 28, 2005). "Free software" licenses could likely be a subset of open source licenses if someone were to take the time to apply to OSI to receive approval to use the "open source" appellation for the already FSF-approved free software licenses.

While occasionally the disagreements between the OSI and the FSF are disputes about which words will best promote the same goals, sometimes the disagreements go deeper and result in substantively different stances. This is best illustrated through an example where the two groups reached a different conclusion about the same license. When Apple Computer released its Apple Public Source License 1.0 (APSL) neither the FSF nor the OSI felt it satisfied their definitions and both groups voiced their concerns. For the FSF's complaints on APSL versions 1.0, 1.1, and 1.2 see The Problems with Older Versions of the Apple Public Source License, at http://www.gnu.org/philosophy/ historical-apsl.html (last modified May 21, 2004). Members of the open source community, were led by Bruce Perens. See The Apple Public Source License - Our Concerns, at http://www.perens.com/Articles/APSL.html (last modified Oct. 11, 2000). Apple responded to some of these concerns, and the OSI approved APSL 1.1 and 1.2 as open source licenses. See The Apple Public Source License Ver. 1.2, at http://www.open source.org/licenses/apsl.php (last visited Feb. 16, 2005). Apple's changes did not initially fully satisfy the FSF, so while the OSI approved APSL 1.1 and 1.2 as "open source" the FSF did not consider them "free software." Apple apparently took the FSF's remaining concerns seriously as it modified the license yet again. See Apple Public Source License Version 2.0, at http://www.opensource.apple.com/apsl (last visited Feb. 16, 2005). When Apple announced APSL 2.0, which incorporated the changes, it trumpeted the fact that the license was now an FSF-approved free software license. Apple Public Source License 2.0 Now a "Free Software License" (July 29, 2003), at http://www.opensource.apple. com/news/2.0-announce.html. OSI certification carries some tangible benefits, but the adoption of APSL 2.0 seems driven primarily by the FSF's concerns. Why would Apple care enough to make such changes? The answer lies in the goals that businesses, such as Apple, have in their "open source" strategy. The primary business benefit of releasing source code to the public is the resulting access to a community of users and developers 


\section{B. Classifying Software Licenses: Copyleft and GPL- Compatibility}

There are several features of a software license that can be useful in classifying it. First, a license may be a proprietary license, a free software license, or an open source license. Secondly, within free software and open source licenses, the license might also be a copyleft, or reciprocal, license. A copyleft license requires that any derivative work made from the copyleft-licensed work be itself licensed under the same copyleft license, preserving all the same rights and responsibilities the original licensee had to downstream licensees. ${ }^{58}$ Third, it is useful to classify licenses according to whether they are compatible with the GPL, since it is the most widely-used free software license. A license is "compatible" with the GPL if that license allows licensees to combine a module that was released under that license with a GPL-covered module to make one larger program. ${ }^{59}$ Note that neither the Free Software Definition nor the Open

who freely contribute back to the project. Businesses that fail to understand or refuse to respect that community do not receive that benefit to as great an extent. While this community contains many who find the FSF's ethical stands out of place in what they see as the practical world of software development, there are also many who agree with and adhere to the FSF's positions. See e.g., JOACHIM HENKEL \& MARK TINS, MUNICH/MIT SURVEY: DEVELOPMENT OF EMBEDDED LINUX (2004) (surveying developers working on embedded platforms), at http://www.linuxdevices.com/files/misc/MunichMIT-Survey_ Embedded_Linux.pdf; INTERNATIONAL INSTITUTE OF INFONOMICS ET. AL., FREE/LIBRE AND OPEN SOURCE SOFTWARE: SURVEY AND STUDY FLOSS Final REPORT, Part IV: Survey of Developers (2002), at http://www.infonomics.nl/FLOSS/report. In a community where one's standing is built in large part on reputation and respect, one ignores the views of the FSF and its adherents at one's peril. Apple understood this and its press release said, "We are grateful to Richard Stallman for his many helpful comments in this process." APSL 2.0 Announcement, supra.

58. See Heffan, supra note 10, at 1491. Copyleft licenses can also be called licenses with a "share alike" clause, because while the licensor allows you to share both the original work and your own modifications, the licensor requires that you share alike, that is, that you offer the same terms to others that were offered to you. Some Creative Commons licenses use such "share alike" terms for copyrighted works other than software, such as photographs or sound recordings. Licenses Explained, Creative Commons, at http://creativecommons.org/learn/licenses (last visited Mar. 6, 2005). The GPL's copyleft provision is found primarily in Section 2(b) which reads, "You must cause any work that you distribute or publish, that in whole or in part contains or is derived from the Program or any part thereof, to be licensed as a whole at no charge to all third parties under the terms of this License." GNU GPL, supra note 34, at Section 2(b). This does not rule out the possibility of dual, triple, or even $n$-tuple licensing schemes, wherein a work is licensed under the GPL as well as under some other license(s). See infra note 103 (discussing example of MySQL).

59. Various Licenses and Comments About Them, supra note 57 at http://www.fsf. org/licensing/licenses/license-list.html\#Introduction. 
Source Definition requires a license to be either a copyleft license or to be GPL-compatible in order to qualify as a free software or open source license, respectively. ${ }^{60}$ Access to source code and the freedoms to use and modify that code are distinct issues, separable from copyleft status or GPL-compatibility.

\begin{tabular}{|c|c|c|}
\hline Proprietary & $\begin{array}{l}\text { (C) All } \\
\text { Rights } \\
\text { Reserved }\end{array}$ & $\begin{array}{l}\text { Permission from copyright-holder required to copy, } \\
\text { modify or distribute covered software. } \\
\text { No access to source code. } \\
\text { Examples: Licenses for Adobe's Photoshop or Intuit's } \\
\text { TurboTax. }\end{array}$ \\
\hline \multirow[t]{3}{*}{$\begin{array}{l}\text { Open } \\
\text { Source } \\
\text { Free Soft- } \\
\text { ware }\end{array}$} & \multirow[t]{3}{*}{$\begin{array}{l}\text { (C) Some } \\
\text { Rights } \\
\text { Reserved }\end{array}$} & $\begin{array}{l}\text { Permission is granted to copy, modify, and distribute the } \\
\text { software under the license's terms. Copyleft and non- } \\
\text { copyleft licenses exist. For both, one must provide ac- } \\
\text { cess to the source code. Distributing copies for a fee } \\
\text { must be allowed, but a royalty cannot be required. Li- } \\
\text { censes may be GPL-compatible or not. }\end{array}$ \\
\hline & & $\begin{array}{l}\text { Copyleft: derivative works allowed only under same } \\
\text { license. } \\
\text { License example: GNU GPL; } \\
\text { Software example: Linux kernel }\end{array}$ \\
\hline & & $\begin{array}{l}\text { Non-copyleft: derivative works under different licenses } \\
\text { allowed. } \\
\text { License example: Modified } \text { BSD }^{62} \text {; } \\
\text { Software example: OpenSSH }\end{array}$ \\
\hline $\begin{array}{l}\text { Public } \\
\text { Domain }\end{array}$ & $\begin{array}{l}\text { No copy- } \\
\text { rights }\end{array}$ & $\begin{array}{l}\text { Everyone is free to copy, modify, or distribute, such } \\
\text { software without asking permission from anyone. } \\
\text { Almost no software has reached the end of its copyright } \\
\text { term, but some code has been donated to the public do- } \\
\text { main, fails the statutory originality requirement, or was } \\
\text { written by the U.S. Government, which generally cannot } \\
\text { receive copyrights. }\end{array}$ \\
\hline
\end{tabular}

60. The Free Software Definition, supra note 41; The Open Source Definition, supra note 47.

61. The FSF maintains a list of licenses that are compatible with the GPL. Various Licenses and Comments About Them, supra note 57, at http://www.fsf.org/licensing/ licenses/license-list.html\#GPLCompatibleLicenses.

62. The BSD License (in template form), supra note 57. The FSF calls it the Modified BSD License while the OSI calls it the New BSD License. It is the same license. It is "New" and "Modified" because it no longer contains the "advertising clause." See Letter of William Hoskins to All Licensees, Distributors of Any Version of BSD (July 22, 1999), at ftp://ftp.cs.berkeley.edu/pub/4bsd/README.Impt.License.Change.

63. 17 U.S.C. $\S 105(2000)$ ("Copyright protection under this title is not available for any work of the United States Government, but the United States Government is not 
As summarized in the chart, the disputes about terminology belie underlying agreement about the nature of the most widely-used licenses in both categories. However, both groups accept that the GPL satisfies their respective definitions and so it is accurately called either an "open source" or a "free software" license.

\section{THE GNU GENERAL PUBLIC LICENSE}

\section{A. Key License Terms}

The Preamble to the GPL is indicative of its intended audience. While the GPL is a legal document and a copyright license, it is not written primarily with a legal audience in mind. Instead, Stallman intended software developers to use this license on their software and for software users to think about software freedoms. ${ }^{64}$ Consequently, the GPL is written in clear language that anyone can understand. ${ }^{65}$ The Preamble concisely explains the FSF's philosophy and the key terms of the license, which are specified in detail later. ${ }^{66}$

\section{Copyleft}

The GPL's Preamble explains the notion of copyleft without introducing the term. ${ }^{67}$ Instead the Preamble states that if you distribute copies of a program licensed under the GPL, "you must give the recipients all the rights that you have." "68 This explains the idea behind copyleft: Something, in this case, software, will be shared with you and you must share alike. Copyleft software is copyrighted, and, indeed, the exclusive rights provided by copyright enable a copyleft license to impose the share alike pro-

precluded from receiving and holding copyrights transferred to it by assignment, bequest, or otherwise.").

64. See GNU GPL, supra note 34, at Preamble ("You can apply it to your programs, too."); $i d$. at "How to Apply These Terms to Your New Programs." The FSF intends the GPL to be a mere license and not a contract. See Eben Moglen, Freeing the Mind: Free Software and the Death of Proprietary Culture, 56 ME. L. REV. 1, 6 (2004) ("[The GPL] requires no acceptance. It requires no contractual obligation. It says you are permitted to do, just don't try to reduce anybody else's rights."); Pamela Jones, The GPL Is a License, Not a Contract, Which Is Why the Sky Isn't Falling (Dec. 14, 2003), at http://www. groklaw.net/article.php?story=20031214210634851; Eben Moglen, Enforcing the GPL (Sept. 10, 2001) [hereinafter Moglen, Enforcing the GPL], at http://www.gnu.org/ philosophy/enforcing-gpl.html.

65. See Daniel Ravicher, Facilitating Collaborative Software Development: The Enforceability of Mass-Market Public Software Licenses, 5 VA. J.L. \& TECH. 11 (2000).

66. See GNU GPL, supra note 34, at Preamble.

67. Id.

68. Id. 
vision on licensees. Copyleft achieves a purpose specified in the Preamble, "To protect your rights, we need to make restrictions that forbid anyone to deny you these rights or to ask you to surrender the rights." ${ }^{\prime 69}$ Licensees are restricted from using GPL-covered code in proprietary derivatives, a restriction motivated by the goal of preserving access to the software for all users. ${ }^{70}$ Copyleft licenses, such as the GPL, prevent someone from turning free software into proprietary software. The copyleft condition of the GPL appears formally in Section 2(b). ${ }^{71}$

\section{Fees}

The GPL's Preamble mentions twice that charging a fee for the distribution of GPL-covered software is not only allowed but a guaranteed right. ${ }^{72}$ This point is often confused with the fact that the GPL forbids requiring that any third party who receives the software pay a license fee. ${ }^{73}$ A license fee would violate Section 6 of the GPL, which reads in relevant part:

Each time you redistribute the Program (or any work based on the Program), the recipient automatically receives a license from the original licensor to copy, distribute or modify the Program subject to these terms and conditions. You may not impose any further restrictions on the recipients' exercise of the rights granted herein. $^{74}$

To require a royalty or license fee of those third parties would be to impose a further restriction on them. In contrast, nothing in the GPL prevents someone from charging fees for service, warranty protection, or indemnification of software licensed under the GPL.

\section{Source Code}

The ability to access, modify, and distribute source code is at the heart of the GPL. The Preamble explains that the license guarantees "that you

69. Id.

70. Id.

71. Id. For the full text of Section 2(b), see supra note 58.

72. "Our General Public Licenses are designed to make sure that you have the freedom to distribute copies of free software (and charge for this service if you wish)" and "if you distribute copies of such a program, whether gratis or for a fee ...." GNU GPL, supra note 34, at Preamble. For rebuttals to several misconceptions about free software, see Joseph Scott Miller, Allchin's Folly: Exploding Some Myths About Open Source Software, 20 CARDOZO ARTS \& ENT. L.J. 491 (2002).

73. See Frequently Asked Questions about the GNU GPL, supra note at 42, http:// www.fsf.org/licensing/licenses/gpl-faq.html\#DoesTheGPLAllowRequireFee.

74. GNU GPL, supra note 34 , at Section 6. 
receive source code or can get it if you want it" 75 and that "you can change the software or use pieces of it in new free programs." Those who distribute GPL-covered software must ensure that recipients "receive or can get the source code." the formal discussion of a licensee's rights and responsibilities regarding source code.

\section{Knowing Your Rights}

The Preamble to the GPL twice emphasizes the importance of informing licensees of their rights. ${ }^{78}$ After listing several software freedoms it provides, the license states that it is designed to make sure "that you know you can do these things."79 Additionally, those who distribute GPLcovered software are informed of their responsibilities to recipients. The license states, "you must show [the recipients] these terms so they know their rights." $"$ This requirement appears formally within Section 1 of the GPL, where those who distribute GPL-covered code are required to "keep intact all the notices that refer to this License and to the absence of any warranty; and give any other recipients of the Program a copy of this License along with the Program." 81 The GPL is in widespread use and many software developers and users are familiar with its terms, perhaps due in part to the requirement that the license text be included. Over time, this has resulted in a savings of transaction costs for software distributors and users. A user familiar with the GPL, upon encountering a new GPLcovered program, can quickly decide whether the license and software suits his purposes. As free software licenses proliferate, however, this time savings is jeopardized. Consequently, both the FSF and the OSI discourage the creation of new licenses where an existing one would suffice. ${ }^{82}$

\section{Patents}

Finally, the Preamble flags a threat to the free software community: patents. The GPL requires that those who would distribute software under

75. Id. at Preamble.

76. Id.

77. Id.

78. Id.

79. Id.

80. Id.

81. Id. at Section 1 .

82. See The Approved Licenses, supra note 57; Licenses, Free Software Foundation, at http://www.fsf.org/licensing/licenses/\#LicenseList (last modified Feb. 14, 2005); OSI Certification Mark and Process, Open Source Initiative, at http://www.opensource.org/ docs/certification_mark.php\#approval (last visited Mar. 6, 2005). 
the GPL not bind themselves to a patent license that would "not permit royalty-free redistribution of the Program by all those who receive copies directly or indirectly through you ...."83 If a developer of GPL-covered software had a patent license that was not available to those who might receive the software, then such recipients would become patent infringers. To avoid this problem the GPL requires such developers either to ensure that the patent holder permits royalty-free redistribution by all or to simply refrain from distributing patented software under the GPL.

\section{B. The GPL and Derivative Works}

Determining when a piece of software is a "derivative work" of a GPL-covered work is critical to the licensing regime, particularly considering the fact that the GPL requires that derivative works that are distributed must also be licensed under the GPL. The lack of certainty regarding what counts as a derivative work is only partially the fault of the GPL. ${ }^{84}$ In general, what constitutes a derivative work within software is not sufficiently clear from either the statutes or the case law. ${ }^{85} \mathrm{~A}$ case providing clear guidelines for assessing derivative software works, even if it had nothing to do with the GPL, would do much to simplify the counseling that attorneys do for their clients on free software licensing issues.

The nature of software is one of the reasons why defining derivative works for software is difficult. Most software is made up of numerous individual programs and files that work together to produce the results the end-user experiences. Software programs also make use of "libraries." A

83. GNU GPL, supra note 34, at Section 7.

84. It is relevant that the GPL chooses to define derivative works by relying solely on copyright law rather than independently defining what will count as a derivative work. This approach was dictated by the FSF's desire to make the GPL a unilateral grant of a license rather than a contract. See supra note 64 . If the FSF had independently defined derivative works, which conflicted with copyright law, then it seems more likely that the recipient of a work licensed under the GPL would have to agree to the FSF's definition, forming a contract. Of course, many may argue that the GPL must or will be interpreted as a contract, so until the courts decide that issue favorably to the FSF, it is not clear whether accepting ambiguity about what counts as a derivative work does more harm than good. One argument that the GPL is a contract is that the license itself constitutes an offer, any copying, modifying, or distribution of a GPL-covered work by a would-be licensee constitutes implied acceptance of that offer, and the licensee's consideration is impliedly promising to abide by the GPL's terms, while the licensor's consideration is the software itself. A simpler complaint about derivative works and the GPL is that the license may define the term in more than one way, providing a possibility of inconsistency. See Phil Albert, A Consumer's Review of the General Public License, LINUXINSIDER, July 20, 2004, at http://www.linuxinsider.com/story/35193.html.

85. Daniel Ravicher, Software Derivative Work: A Circuit Dependent Determination (2002), at http://www.pbwt.com/Attorney/files/ravicher_1.pdf. 
library is a collection of subprograms used to develop software. "Libraries are distinguished from executables in that they are not independent programs; rather, they are 'helper' code that provides services to some other independent program." ${ }^{\text {,7 }}$ A library may be either statically or dynamically linked to the independent programs that it helps. ${ }^{88}$

Static linking involves embedding the library in the independent program when it is compiled. ${ }^{89}$ A dynamically linked library is not incorporated into a program, rather it exists both in its own place on a computer's hard drive and in its own memory space while in use. ${ }^{90}$ Multiple programs might even be dynamically linked to the same library and communicate with it while it sits in a single memory space. ${ }^{91}$ Consequently, some have argued that a proprietary program could dynamically link to a library licensed under the GPL, or a program licensed under the GPL could dynamically link to a proprietary library, and in neither case would a "derivative work" of the GPL-covered work be created, since the two programs retain distinct existences and only tenuous connections. ${ }^{92}$

This is not the view of the FSF, however. ${ }^{93}$ The FSF argues that even dynamic linking creates a derivative work, and has written a different license, the GNU Lesser General Public License (LGPL), for those who wish to permit such proprietary linking. ${ }^{94}$ However, the FSF does not recommend the use of the LGPL, as the FSF ultimately sees the LGPL as encouraging an unhealthy reliance on proprietary software, and it would prefer that the needed proprietary software, which would be linked, be rewrit-

86. Library (computer science), WIKIPEDIA: THE FREE ENCYLOPEDIA, at http://en. wikipedia.org/wiki/Library_(computer_science) (last modified Feb. 8, 2005).

87. Id.

88. Id.

89. Id. "Compiling" refers to the act of turning human-readable source code into machine-readable binary code.

90. Id.

91. Id.

92. Lawrence Rosen, The Unreasonable Fear of Infection 2 (2001), at http://www. rosenlaw.com/html/GPL.PDF (last visited Feb. 16, 2005), states that:

Dynamic linking, on the other hand, is a transitory relationship between two programs for which they are each pre-designed. The linking program need not be modified to implement the linkage. For example, a printer driver for a new printer can be installed in a program without modifying the source code of the original program. Such linkage does not constitute the creation of a derivative work.

93. See Richard Stallman, Why You Shouldn't Use the Library GPL for Your Next Library, Feb. 1997, at http://www.gnu.org/philosophy/why-not-lgpl.html.

94. The GNU Lesser General Public License, supra note 28. 
ten, and licensed under a free software license. ${ }^{95}$ Ultimately, the issue of what constitutes a derivative software work must be addressed by statute or the courts. There was some hope that the issue would be decided in a case from 2002, but the court did not reach this issue. ${ }^{96}$

\section{Software Patents and Free Software}

Many within the free software community now believe that software patents are the greatest threat to open source and free software. ${ }^{97}$ A report by Open Source Risk Management found that 283 granted patents could potentially be used against the Linux kernel. ${ }^{98}$ However, none of these patents have been tested in court, and there is no indication that the Linux kernel is any more susceptible to such claims than other large software projects. ${ }^{99}$ Rather, it is likely that most any software project that reaches the size of the Linux kernel would be subject to similar threats from patents. ${ }^{100}$ Most proprietary software gains some protection from this problem through obscurity. Since proprietary code is seldom released to users, it is more difficult to identify potentially infringing processes.

The free software community is well aware of the threat of software patents. IBM, now a major contributor to free software projects, has pledged not to assert its massive patent portfolio against the Linux kernel. ${ }^{101} \mathrm{GNU} /$ Linux provider Red Hat prominently displays a "patent promise" on its website that states "software patents generally impede innovation" and pledges Red Hat's patents will not be used offensively against an open source or free software project. ${ }^{102} \mathrm{MySQL} \mathrm{AB}$, which provides its

95. Stallman, supra note 93.

96. Progress Software Corp. v. MySQL AB, 195 F. Supp. $2 d 328$ (D. Mass. 2002) (holding that the defendant demonstrated a substantial likelihood of success on breach of contract claim concerning its trademark); see Laura Majerus, Court Evaluates Meaning of "Derivative Work" in an Open Source License (Fall 2002), available at http://www. fenwick.com/docstore/publications/IP/IP_bulletins/IP_Bulletin_Fall_2002.pdf.

97. Richard Stallman, Fighting Software Patents-Singly and Together, at http:// www.gnu.org/philosophy/fighting-software-patents.html (last modified Feb. 11, 2005).

98. Press Release, Open Source Risk Management, Results of First-Ever Linux Patent Review Announced, Patent Insurance Offered (Aug. 2, 2004), available at http:// www.osriskmanagement.com/press_releases/press_release_080204.pdf.

99. Steven J. Vaughan-Nichols, Author of Linux Patent Study Says Ballmer Got It Wrong, eWEEK, Nov. 19, 2004, at http://www.eweek.com/print_article2/0,2533,a=1396 69,00.asp.

100. Id.

101. Stephen Shankland, IBM Pledges No Patent Attacks Against Linux, CNET NEws.COM, Aug. 4, 2004, at http://news.zdnet.com/2100-3513_22-5296787.html.

102. Red Hat, Inc., Statement of Position and Our Promise on Software Patents, at http://www.redhat.com/legal/patent_policy.html (last visited Feb. 16, 2005). 
MySQL database software under a dual-licensing scheme, providing the software under either the GPL or an alternative license, prominently links to www.nosoftwarepatents.com from every page on its site. ${ }^{103}$ MySQL AB's patent policy declares,

We do not think that software patents are a useful way to protect software IP. Instead, we believe that copyright protection is sufficient. We have concluded that software patents are harmful to the software industry at large. This is why we support those who work for an abolishment of software patents. We also work with other companies and groups to build a joint defense against software patents. ${ }^{104}$

The FSF also opposes software patents, and Richard Stallman regularly discusses how he believes they stifle innovation. ${ }^{105}$ There is also a highly organized effort to prevent laws that would allow the patenting of software in Europe. ${ }^{106}$

103. Stacey Quandt, Taking Open Source to the Bank: Open Source and Profit Are Not Oxymorons, LINUX MAG., Sept. 2004, at http://www.linux-mag.com/2004-09/bank_ 01.html. Quandt also discusses the dual-licensing strategies of Sleepycat Software and Trolltech. The MySQL database software is often tightly integrated with other software applications. Developers of those applications have a choice: They can download and use MySQL at no cost under the terms of the GPL; however, they will likely be required to provide the source code of the applications they distribute if their application is integrated with MySQL in the relevant ways. See MySQL Commercial License, MySQL, at http:// www.mysql.com/company/legal/licensing/commercial-license.html (last visited Mar. 6, 2005) (listing situations where MySQL AB believes that you would either need to release your source or get their "commercial" license). Alternatively, developers can pay for a "commercial" license that allows licensees to keep private the source to their distributed applications, which are integrated with MySQL. MySQL AB can implement this duallicensing scheme because it holds the copyrights to all of its software and asks the developers that submit modifications to assign their copyrights to MySQL AB. See MySQL Lists: mysql: Re: Index Create Speed, MySQL, at http://lists.mysql.com/mysql/84008 (posting from Michael Widenius, CTO, MySQL AB, to MySQL General Discussion (Aug. 30, 2001)). The use of the term "commercial" in MySQL AB's commercial license, which serves as an alternative to the GPL, is misleading because the GPL guarantees the right to distribute copies of a GPL-covered program for a fee-that is, commercially. See supra Part III.A.2.

104. MySQL Public Patent Policy, MySQL, at http://www.mysql.com/company/ legal/patents.html (last modified Sept. 1, 2004). For the view that computer software in machine readable form should not be afforded copyright; and favoring a sui generis approach instead, see Pamela Samuelson, CONTU Revisited: The Case Against Copyright Protection For Computer Programs In Machine-Readable Form, 1984 DUKE L.J. 663; Pamela Samuelson et al., A Manifesto Concerning the Legal Protection of Computer Programs, 94 ColuM. L. REV. 2308 (1994).

105. Stallman, supra note 97.

106. Software Patents vs Parliamentary Democracy, at http://swpat.ffii.org (last visited Mar. 6, 2005). 
The free software community is particularly concerned about software patents because many free software projects lack the financial and institutional resources necessary to defend themselves in patent litigation. Patent litigation is notoriously expensive. ${ }^{107}$ Additionally, the nature of software itself, in which each individual program can make use of so many ideas, is cited as making software patents particularly problematic, because literally hundreds of patents sometimes cover the ideas implemented in a single software program. ${ }^{108}$ There are numerous other reasons for being dissatisfied with the current way patents are granted for software in the United States, many of which are shared even by those outside the free software community.

IBM and Sun Microsystems have recently illustrated one approach to mitigating the harmful side effects of software patents on free software

107. Mark A. Lemley, Rational Ignorance at the Patent Office, 95 Nw. U. L. REV. 1495,1502 (2001) ("When patent litigation does occur, it is expensive. The American Intellectual Property Law Association reports, based on a survey of its members, that the median cost of patent litigation to each side is $\$ 799,000$ through the end of discovery, and $\$ 1,503,000$ through trial and appeal.').

108. Stallman, supra note 97.

109. See, e.g., Viva R. Moffat, Mutant Copyrights and Backdoor Patents: The Problem of Overlapping Intellectual Property Protection, 19 BERKELEY TECH. L.J. 1473, 1512 (2004) ("[O]verlapping protection disrupts the federal intellectual property system, frustrates the patent and copyright bargains, and meddles with the incentive structures. Moreover, overlapping protection imposes a host of unnecessary costs on intellectual property owners, litigants, third parties, and the public."). Julie E. Cohen \& Mark A. Lemley state:

The extent to which the patent system is actually necessary to induce innovation that would not otherwise occur is an unanswered, and perhaps unanswerable, empirical question .... The bewildering variety of software innovations generated in the years before software was considered patentable suggests that for software, at least, patent protection may not be as necessary as the reward theory assumes. The question is complicated, however, by the availability of copyright protection for software during that period, and by uncertainty over both the scope of copyright protection and the degree of overlap between the copyright and patent models of protection.

Julie E. Cohen \& Mark A. Lemley, Patent Scope and Innovation in the Software Industry, 89 CALIF. L. REV. 1, 5 n.5 (2001); see also Robert P. Merges, One Hundred Years of Solicitude: Intellectual Property Law, 1900-2000, 88 CALIF. L. REV. 2187, 2230 (2000) ("Concerning the interim period when software patents were in doubt, however, at least this much can be said: The industry learned to work around the absence of patent protection quite nicely. There was no shortage of technical innovation and new commercial products. Perhaps something about software provided profits ample enough to induce entry and innovation even in the absence of patents."); Samuelson et al., supra note 104, at $2343-47$. 
and open source development. IBM went beyond its earlier pledge not to use its patents against the Linux kernel and dedicated 500 of its existing software patents to a "patent commons" for use by any developer working on software licensed under an OSI-approved license. ${ }^{110}$ Sun Microsystems followed and announced that it would provide licenses at no cost to more than 1,600 of its software patents related to its Solaris operating system, which it also intends to release under an OSI-approved license, the Common Development and Distribution License ("CDDL")." Sun's announcement was immediately questioned to gain clarification of what exactly Sun had pledged, particularly whether Sun's patents would be $1 \mathrm{i}$ censed to all developers working under an OSI-approved license or merely to those contributing to the new open source version of Solaris. ${ }^{112}$ Sun acknowledged the confusion and said, "Clearly we have no intention of suing open-source developers." 113 However, Sun ultimately conceded that its patent grant restricts the use of the pledged patents to projects licensed under Sun's CDDL. ${ }^{114}$

While the free software community would likely appreciate even more support from patent holders, ultimately, the community's greatest defense may be its very method of operating. Almost every free software project

110. Feast for Open Source As IBM Opens Patent Pantry, IBM, at http://www.ibm. com/news/us/en/2005/01/patents.html (last visited Mar. 6, 2005); Press Release, IBM, IBM Pledges 500 U.S. Patents To Open Source In Support Of Innovation and Open Standards (Jan. 11, 2005), available at http://www.ibm.com/press/PressServleForm.wss? TemplateName $=$ ShowPressReleaseTemplate $\&$ SelectString $=\mathrm{t} 1$.docunid $=7473$; Jim Wagner, IBM Pledges Patents to Open Source, INTERNETNEWS.COM, Jan. 11, 2005, at http:// www.internetnews.com/dev-news/article.php/3457381.

111. Press Release, Sun Microsystems, Sun Grants Global Open Source Community Access to More than 1,600 Patents (Jan. 25, 2005), available at http://www.sun.com/ smi/Press/sunflash/2005-01/sunflash.20050125.2.html.

112. Bruce Perens, The Open-source Patent Conundrum, CNET NEws.COM, Jan. 31, 2005, at http://news.com.com/The+open+source+patent+condundrum/2010-1071_3-555 7340.html; Michael Singer, Sun Solaris Patent Release Questioned, INTERNETNEwS.COM, Jan. 28, 2005, at http://www.internetnews.com/bus-news/print.php/3465901; Richard Stallman, Sun's No-op Announcement, NEwSFORGE, Jan. 31, 2005, at http:// trends.newsforge.com/print.pl?sid=05/01/31/1310231; Letter from Daniel Ravicher, Executive Director, Public Patent Foundation, to Scott McNealy, Chairman and CEO, Sun Microsystems, Inc. (Jan. 8. 2005), available at http://www.pubpat.org/PUBPAT_Ltr_re_ Sun_Patent_Grant.pdf.

113. Stephen Shankland, Sun: Patent Use OK Beyond Solaris Project, CNET NEws.COM, Jan. 31, 2005, at http://news.zdnet.com/2102-9593_22-5557658.html see also Philip H. Albert, OpenSolaris: Beyond the Rhetoric, LINUXINSIDER, Feb. 1, 2005, at http://www.linuxinsider.com/story/OpenSolaris-Beyond-the-Rhetoric-40176.html.

114. Peter Galli, Sun Criticized for Limitations on Patent Release, eWeek, Feb. 7, 2005, at http://www.eweek.com/article2/0,1759,1761720,00.asp. 
posts its code on the Internet for all to browse or download. Patents are only available if one can satisfy, inter alia, the statutory novelty and nonobviousness requirements. ${ }^{115}$ Those who seek to challenge or invalidate a patent can reference prior art in order to show that something was not novel or that it was obvious given the prior art. ${ }^{116}$ As free software projects post more and more code to the Internet, they are in the process of building the largest repository of software prior art in existence. Since most proprietary source code is never publicly disclosed, it can be difficult for a patent examiner to say whether a process in a software patent application is truly novel or nonobvious.

\section{ENFORCEMENT OF THE GPL}

Historically, the GPL has been primarily enforced through private negotiation and settlement agreements. This process has been successful thus far because most alleged violators have apparently been eager to correct any defects in their compliance. These extra-judicial resolutions have generally satisfied the goals of the copyright holders enforcing the GPL, but left the question of the GPL's enforceability in court largely unanswered. In 2004, however, two cases began to illuminate how courts will enforce the GPL.

115. See 35 U.S.C. $\S 102$ (2000). Section 102 states that:

A person shall be entitled to a patent unless-

(a) the invention was known or used by others in this country, or patented or described in a printed publication in this or a foreign country, before the invention thereof by the applicant for patent, or

(b) the invention was patented or described in a printed publication in this or a foreign country or in public use or on sale in this country, more than one year prior to the date of the application for patent in the United States....

Id.

116. See id. $\S 103$. Section 103 states that:

A patent may not be obtained though the invention is not identically disclosed or described as set forth in section 102 of this title [35 U.S.C. $\S 102$ ], if the differences between the subject matter sought to be patented and the prior art are such that the subject matter as a whole would have been obvious at the time the invention was made to a person having ordinary skill in the art to which said subject matter pertains.... 


\section{A. Private GPL Enforcement by the Free Software Foundation}

The only party who can license a work under the GPL is the copyright holder. Consequently, the only party who can seek a remedy for violation of the GPL as applied to that work is the copyright holder. There is a misconception that because the FSF wrote the GPL that it is therefore the enforcement police for all software licensed under the GPL. ${ }^{117}$ While the FSF is often willing to help, and asks to be informed of GPL violations, ${ }^{118}$ ultimately the copyright holder is responsible for enforcement. The FSF does hold the copyrights to many widely-used free software programs, particularly those within its GNU project. ${ }^{119}$ For those programs, the FSF does handle enforcement, primarily through its pro bono general counsel. $^{120}$

The FSF engaged in an interesting public example of private enforcement of the GPL in 2003. Linksys was distributing its popular WRT54G wireless router with GPL-covered software, but was not providing source code. ${ }^{121}$ Initial discussions with Linksys were not moving fast enough to

117. Robert McMillan, SCO: IBM Can't Enforce GPL Software License, COMPUTERWORLD, Oct. 28, 2003, at http://www.computerworld.com/printthis/2003/0,4814, 86587,00.html.

118. Violations of the GPL, LGPL, and GFDL, Free Software Foundation, at http://www.fsf.org/licensing/licenses/gpl-violation.html (last modified Feb. 12, 2005).

119. FSF/UNESCO, Free Software Directory, Free Software Foundation, at http:// directory.fsf.org/GNU (last visited Mar. 6, 2005).

120. Moglen, Enforcing the GPL, supra note 64. Moglen reports encountering little difficulty in these private enforcement actions. He investigates GPL violations "dozens of times a year." Id. FSF's Executive Director, Bradley Kuhn, said there were thirty such actions ongoing in October 2003 and that fifty hand been handled during 2002. Daniel Lyons, Linux's Hit Men, ForBES.COM, Oct. 14, 2003, at http://www.forbes.com/2003/10

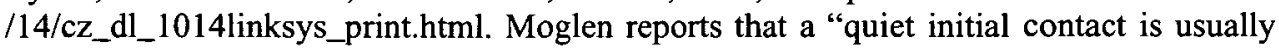
sufficient to resolve the problem. Parties thought they were complying with GPL, and are pleased to follow advice on the correction of an error." Moglen, Enforcing the GPL, supra note 64. He also explains that the enforceability of the GPL is not in doubt in these discussions. Well-advised companies down to individual developers all decide it is better to comply than fight. Moglen demonstrates his powers of persuasion when he shares some details of these conversations: "[P]eople all over the world are pressuring me to enforce the GPL in court, just to prove I can. I really need to make an example of someone. Would you like to volunteer?" Id. So far, no one has. Moglen insists that the FSF's goals are not litigation, but "compliance with the license, and security for future good behavior ...."Id.

121. Zack Brown, More On Possible GPL Violations By Wireless Vendors, Kernel Traffic (June 24, 2003), at http://www.kerneltraffic.org/kernel-traffic/kt20030708_221. html\#8; Zack Brown, Possible GPL Violations By Many Wireless Vendors, Kernel Traffic (June 7, 2003), at http://www.kerneltraffic.org/kernel-traffic/kt20030616_219.html \#16. A router is a computer networking device that forwards data packets toward their destinations through a process of discovering paths along which information can be sent. 
satisfy some developers of the Linux kernel. ${ }^{122}$ The FSF stepped in to negotiate with Linksys' new owner, Cisco Systems, who eventually complied with the license and now provides the GPL-covered source code from the Linksys website for not only the WRT54G, but also for dozens of Linksys devices using GPL-covered software. ${ }^{123}$ Consequently, this router has become particularly popular among hackers, ${ }^{124}$ who have even developed projects to install more full-featured GNU/Linux installations on the router.

\section{B. Private GPL Enforcement by Other Copyright Holders}

The FSF is not the only copyright holder who licenses software under the GPL and who has had significant success enforcing the GPL privately. One of the more prominent examples of such private enforcement is provided by Harald Welte, who would later be the plaintiff in this year's Munich court decision enforcing the GPL. Welte is the head member of the Netfilter/iptables core software development team. ${ }^{126}$ The netfilter/iptables software acts as a firewall for GNU/Linux systems ${ }^{127}$ and is in widespread

Router, WIKIPEDIA: THE FREE ENCYCLOPEDIA, at http://en.wikipedia.org/wiki/Router (last modified Feb. 16, 2005); Routing, WIKIPEDIA: THE FREE ENCYCLOPEDIA, at http:// en.wikipedia.org/wiki/Routing (last modified Jan. 26, 2005).

122. Linksys GPL Issues Raise Embedded Concerns, LINUXDEVICES.COM, Oct. 14, 2003, at http://www.linuxdevices.com/cgi-bin/printerfriendly.cgi?id=NS77 19522768; Lyons, supra note 120; Zack Brown, Possible Linksys GPL Violations: The Saga Continues, Kernel Traffic, Oct. 24, 2003, at http://www.kerneltraffic.org/kernel-traffic/kt20031 024_235.html\#8.

123. Linksys GPL Code Center, Cisco Systems, Inc., at http://www.linksys.com/ support/gpl.asp (last visited Mar. 6, 2005).

124. This Note uses the term 'hacker' in its original sense of "a person who enjoys exploring the details of programmable systems and how to stretch their capabilities ...." See Eric S. Raymond, The New Hacker Dictionary, available at http://www.catb.org/ $\sim$ esr/jargon/html/H/hacker.html (last visited Mar. 6, 2005). This is opposed to the popular media sense of "[o]ne who breaks security on a system." The New Hacker Dictionary, available at http://www.catb.org/ esr/jargon/html/C/cracker.html (last visited Mar. 6, 2005).

125. Jim Buzbee, Linux on the WRT54G (Jan. 15. 2005), at http://www.batbox. org/wrt54g-linux.html.

126. Other active members include Jozsef Kadlecsik, Martin Josefsson, and Patrick McHardy. The core team previously included James Morris, Marc Boucher, and Rusty Russell, who were critical to the project's early success. About the Netfilter/iptables Project: The Netfilter Core Team, Netfilter, at http://www.netfilter.org/about.html\#coreteam (last visited Mar. 6, 2005).

127. Netfilter/iptables Project Homepage, Netfilter, at http://www.netfilter.org (last visited Mar. 4, 2005). "A firewall is a piece of hardware or software which functions in a networked environment to prevent some communications forbidden by the security policy, analogous to the function of firewalls in building construction." Firewall (network- 
use, especially in hardware routers. ${ }^{128}$ The netfilter software is itself a part of the Linux kernel and since its source code is freely available on the web, it becomes a natural choice for inclusion by many device manufacturers. Problems arise when these device manufacturers do not understand or ignore the licensing terms under which the software is provided. Manufacturers that distribute modified versions of the software are required by the GPL to provide both the full text of the GPL license itself, as well as the source code to the modified software they are distributing. ${ }^{129}$ Several manufacturers have failed to do this, and Harald Welte has sought to enforce the terms of the GPL against them. ${ }^{130}$

Welte's first success came in February 2004, when he announced an out-of-court settlement with Allnet GmbH. ${ }^{131}$ Allnet was offering two routers, both including software developed by the netfilter/iptables project. ${ }^{132}$ However, Allnet did not fulfill the obligations of the GPL regarding the netfilter/iptables software because it did not make any source code offering or include the terms of the GPL with its products. ${ }^{133}$ In the settlement, Allnet agreed to adhere to all clauses of the license and to inform its customers about their respective rights and obligations under the GPL. ${ }^{134}$ Allnet also agreed to refrain from offering any new netfilter/iptables based products without adhering to the GPL. ${ }^{135}$ Finally, Allnet made "a significant donation" to the FSF Europe ${ }^{136}$ and to the Foundation of a Free Information Infrastructure. ${ }^{137}$

Buoyed by this success, Welte pursued similar successful GPLenforcement actions against Fujitsu-Siemens, ASUS, and Securepoint be-

ing), WIKIPEDIA: THE FREE ENCYCLOPEDIA, in http://en.wikipedia.org/wiki/Firewall_ (networking) (last modified Feb. 16, 2005).

128. Harald Welte, Harald Welte's Blog, at http://gnumonks.org/ laforge/weblog/ linux/gpl-violations (last visited Mar. 6, 2005).

129. GNU GPL, supra note 34 , at Section 1.

130. Welte, supra note 128 . Welte also operates the gpl-violations.org project which "tries to raise public awareness about past and present infringing use(r)s of GPL licensed software." See The GPL-Violations Project?, gpl-violations.org, http://www.gplviola tions.org (last visited Mar. 6, 2005).

131. Allnet GmbH Resolves Iptables GPL Violation, LWN.NET, Feb. 17, 2004, at http://lwn.net/Articles/71418.

132. Id.

133. Id.

134. Id.

135. Id.

136. See Freesoftware Foundation Europe, supra note 25.

137. Foundation for a Free Information Infrastructure, at http://www.ffii.org (last visited Mar. 6, 2005). 
fore coming across a violator of the GPL that was reluctant to comply with the license's terms: Sitecom Germany GmbH.

\section{Judicial Enforcement of the GPL: The Munich District Court Decisions}

The first clear resolution of the GPL's enforceability came this year from a German district court in Munich hearing Welte's case against Sitecom. The court held that the GPL was a valid and enforceable copyright license.

\section{Background}

Sitecom Germany, a subsidiary of Netherlands-based Sitecom Europe B.V., sold a wireless router, the WL-122, which contained the netfilter project's firewalling software, iptables, in binary form. ${ }^{138}$ Sitecom was not providing source code to those to whom it distributed the WL-122 routers, nor was it providing a copy of the GPL license as required. ${ }^{139}$ On March 18,2004 , Welte notified Sitecom of these violations of the GPL. ${ }^{140} \mathrm{By}$ April 1, after discussions had stalled, Welte filed an application for a preliminary injunction with the Munich District Court. ${ }^{141}$ The court issued injunction the following day and enjoined Sitecom from distributing, copying, or making available to the public the software netfilter/iptables without at the same time "making reference to the licensing under the GPL and attaching the license text of the GPL as well as making available the source code of the software netfilter/iptables free of any license fee." Sitecom filed an objection to the preliminary injunction on April 20, $2004 .^{143}$

138. Welte v. Sitecom Deutschland GmbH, LG (Munich) (2004), available at http:// www.jbb.de/urteil_lg_muenchen_gpl.pdf (May 19, 2004) (official publication in German). Jaschinski Biere Brexl (JBB), Welte's attorneys, provided an unofficial English translation on their firm website. JBB, Welte v. Sitecom Deutschland GmbH, No. 210 6123/04 (Dist. Ct. of Munich 2004) [hereinafter Welte translation], at http://www.jbb.de/ judgment_dc_munich_gpl.pdf. See also Thomas Hören \& Christian Ahlert, District Court of Munich I, Judgement of 19/05/2004-file reference: 210 6123/04 (Open Sourceeffectiveness of GPL), at http://www.oii.ox.ac.uk/resources/feedback/OIIFB_GPL2_200 40903.pdf (last visited Mar. 6, 2005) (English translation provided by the Oxford Internet Institute).

139. Welte translation, supra note 138 , at 4.

140. Id.

141. Id. at 4-5.

142. Id. at 5 .

143. Id. 


\section{The Munich Court's Holding}

On May 19, 2004, the court upheld the preliminary injunction. ${ }^{144}$ Welte argued that only the copyright holder can give someone permission to copy, modify, or distribute its copyrighted software. ${ }^{145}$ If a copyright holder chooses to license its software under the GPL and nothing else, then anyone who copies, modifies, or distributes that software must either be in compliance with the terms of the license, or be deemed an infringer of the copyright. ${ }^{146}$ Welte argued that, since netfilter/iptables is only offered under the GPL, Sitecom must either comply or be held an infringer. ${ }^{147}$

The court focused its analysis on the termination clause in Section 4 of the GPL. ${ }^{148}$ It held that this clause was valid under German law, and further stated that regardless of the validity of the second and third sentences in the section, the first sentence-_"You may not copy, modify, sublicense, or distribute the Program except as expressly provided under this License."-would remain valid. ${ }^{149}$

This was an important victory for the GPL, because the court agreed that a copyright holder could adopt the GPL as the sole licensing mechanism and could refuse to allow copying, modification, or distribution under any other terms. ${ }^{150}$ The court clearly differentiated between licensing software under the GPL and placing software in the public domain. ${ }^{151}$ The court noted that,

[T] he Panel shares the view that one cannot regard the conditions

of the GPL (General Public License) as containing a waiver of copyright and related legal rights. On the contrary, the users

\footnotetext{
144. Id. at $8,13$.

145. Id. at 5-7.

146. Id.

147. Id.
}

148. Id. at 8-12. The clause states in full:

You may not copy, modify, sublicense, or distribute the Program except as expressly provided under this License. Any attempt otherwise to copy, modify, sublicense or distribute the Program is void, and will automatically terminate your rights under this $\mathrm{Li}$ cense. However, parties who have received copies, or rights, from you under this License will not have their licenses terminated so long as such parties remain in full compliance.

GNU GPL, supra note 34, at Section 4.

149. Welte translation, supra note 138 , at 12 .

150. See id. at 8 (stating that the conditions of the GPL are not a waiver of copyright).

151. This is not to say that there is any legal impediment to donating software to the public domain, rather it is to say that those who choose to license their software under the GPL have not done so and retain their copyrights. 
avail themselves of the conditions of copyright, in order to guarantee and carry out their conceptions of the further development and dissemination of software. ${ }^{152}$

The court further held that Sections 2 and 3 of the GPL, which are the heart of the GPL and implement both its copyleft nature and its requirement of providing source code, were valid. ${ }^{153}$ The court added that even if the GPL were invalid as a whole, then the result would be that any use of the software would be illegal, because all uses would be unlicensed infringements without the GPL acting as a license. ${ }^{154}$ In effect, the court adopted Welte's argument that Sitecom Germany must either comply with the terms of the license or be considered an infringer.

Harald Welte has reported that the significant media attention brought by this first successful court test of the GPL has only brought more viola-

152. Welte translation, supra note 138 , at 8 (with minor modifications of the translation for style).

153. Id. at 12. GNU GPL, supra note 34, at Section 2, reads in part:

You may modify your copy or copies of the Program or any portion of it, thus forming a work based on the Program, and copy and distribute such modifications or work under the terms of Section 1 above, provided that you also meet all of these conditions: [T] a) You must cause the modified files to carry prominent notices stating that you changed the files and the date of any change. [ $\$$ ] $b$ ) You must cause any work that you distribute or publish, that in whole or in part contains or is derived from the Program or any part thereof, to be licensed as a whole at no charge to all third parties under the terms of this License.

GNU GPL, supra note 34, at Section 3, reads in part:

You may copy and distribute the Program (or a work based on it, under Section 2) in object code or executable form under the terms of Sections 1 and 2 above provided that you also do one of the following: [7] a) Accompany it with the complete corresponding machine-readable source code, which must be distributed under the terms of Sections 1 and 2 above on a medium customarily used for software interchange; or, [q] b) Accompany it with a written offer, valid for at least three years, to give any third party, for a charge no more than your cost of physically performing source distribution, a complete machine-readable copy of the corresponding source code, to be distributed under the terms of Sections 1 and 2 above on a medium customarily used for software interchange; or, [T] c) Accompany it with the information you received as to the offer to distribute corresponding source code. (This alternative is allowed only for noncommercial distribution and only if you received the program in object code or executable form with such an offer, in accord with Subsection b above.)

154. Welte translation, supra note 138 , at 12. 
tions to light. ${ }^{155}$ Within a week of Sitecom's May 19th appeal, Welte learned of and commenced enforcement against three more potential infringers. $^{156}$

This raises the question: Why enforce the license? The netfilter/iptables project provides its software at no cost. Welte did not win damages, but rather an injunction and GPL compliance. If he had lost, under German law, he would have had to pay attorneys fees, and these enforcement actions take up valuable time. ${ }^{157}$ What motivates those, like Welte, that seek to enforce the GPL? The answer can be found in the philosophy driving the GPL itself. The netfilter team members are among those free software developers who have given some thought to their choice of license, and chose the GPL for the work that it does as a license. The license keeps one's copyrighted work available in the manner one chooses. Software developers spend a great deal of time creating such software, and when they are not being paid directly for that work, there is even more reason to think they may seek other forms of compensation for the long hours, such as the assurance that others will always be able to study, modify, improve, and share the work that they have begun. ${ }^{158}$ Welte is one of many free software developers who has made a conscious choice

155. Welte, supra note 128.

156. Id.

157. Since Welte won twice, Sitecom had to pay his attorneys' fees. Additionally, unlike in the United States, attorney fees are regulated in Germany and Welte can more accurately assess his monetary risk in advance of each enforcement action.

158. See Pamela Samuelson, Mapping the Digital Public Domain: Threats and Opportunities, 66 LAW \& CONTEMP. PROBS. 147, 167-68 (2003). Professor Samuelson has stated:

From the standpoint of many open source developers, dedicating a program to the public domain is a suboptimal strategy for achieving open source objectives because proprietary derivatives can be made of public domain programs. Those who breach the terms of an open source license by making a proprietary derivative program will be deemed infringers of the underlying intellectual property rights in the program and may be enjoined from this form of freeriding on open source.development. Thus, open source licenses use property rights to preserve and maintain a commons in an existing intellectual resource.

Id.; see also Robert P. Merges, A New Dynamism in the Public Domain, 71 U. CHI. L. REV. 183, 192 (2004) ("[B]y eschewing property rights, a large number of independent contributors can create and integrate components into a single, useable asset with minimal transaction costs."). 
to use the GPL because it prevents others from making proprietary derivatives of his work. $^{159}$

\section{Court Discussion of the GPL in the United States: $S C O$ v. IBM}

Though version 2 of the GPL was released in 1991, no U.S. court has ruled on its enforceability in the ensuing fourteen years. Indeed, the GPL has only been mentioned in passing in U.S. courts. ${ }^{160}$ However, in March of 2003, Caldera Systems, Inc., doing business as The SCO Group, filed a complaint against IBM in Utah state court, ${ }^{161}$ alleging misappropriation of trade secrets, unfair competition, interference with contract, and breach of

159. When asked why he pursued this legal action, Welte said, "Because I write code under the GPL and not the BSD license." E-mail from Harald Welte, Head Member, Netfilter Care Team, to Brian W. Carver, Law Student, University of California at Berkeley, School of Law (Boalt Hall) (Jan. 3, 2005) (on file with author). The BSD license is not a copyleft license and allows proprietary derivatives. See Various Licenses and Comments About Them, supra note 57. Welte's response is indicative of those who purposefully choose to license their works under the GPL as a means of guaranteeing that derivatives of their efforts remain free software. Linus Torvalds, the lead developer of the Linux kernel, has expressed similar motivations. Torvalds said:

I really want a license to do just two things: make the code available to others, and make sure that improvements stay that way. That's really it. Nothing more, nothing less. Everything else is fluff. It may sound like a very simple concept, but even most opensource licenses fail my criteria very fundamentally. They tend to fail in allowing somebody to limit the availability of improvements some way.

Stephen Shankland, Torvalds: A Solaris Skeptic, CNET NEWs.com, Dec. 21, 2004, at http://news.com.com/2102-1082_3-5498799.html?tag=st.util.print.

160. In Computer Associates International v. Quest Software, Inc., the district court relied on the terms of the GPL, in particular an exception added to it, to reach the decision that the GPL was not being violated. 333 F. Supp. 2d 688, 698 (N.D. Ill. 2004). The court wrote, "Any user of that [GPL-covered] code is, however, bound by the terms of the GNU General Public License (GPL). The GPL puts restrictions on the modification and subsequent distribution of freeware [sic] programs." Id. While the court mistakenly used the term "freeware" to describe "free software," it appears that the court accepted the legitimacy of the copyleft concept within the GPL. Software that is commonly referred to as "freeware" is usually provided at no cost under a proprietary license and typically does not include access to source code. See Richard M. Stallman, Words to Avoid, in Free Software, Free Society: Selected Essays of Richard M. Stallman (Joshua Gay ed., 2002), available at http://www.fsf.org/licensing/essays/words-to-avoid. html.

161. SCO mistakenly alleged that IBM was a Delaware corporation in its complaint, but IBM is incorporated in New York. The case was removed to the Federal District Court of Utah soon after the complaint was filed. 
contract. ${ }^{162}$ SCO claimed that while it was working with IBM on "Project Monterey," a project to develop enterprise-class UNIX systems on Intel processor-based platforms, ${ }^{163}$ IBM allegedly misappropriated SCO's proprietary knowledge. ${ }^{164}$ IBM's misappropriation was allegedly in the form of contributions of SCO's property to GNU/Linux systems in order to destroy the value of UNIX systems, and thereby, of SCO's business. ${ }^{165}$

The case immediately generated significant media coverage, partly because (1) SCO alleged damages of not less than one billion dollars; ${ }^{166}$ (2) SCO hired prominent attorney David Boies of Boies, Schiller and Flexner; ${ }^{167}(3)$ the claims SCO made in its complaint depicted GNU/Linux in

162. Complaint Tף 104-36, Caldera Sys. Inc. v. Int'l Bus. Machs. Corp. (Utah 2003) [hereinafter Complaint], available at http://www.sco.com/ibmlawsuit/complaint3.06.03. html. It is notable that this initial complaint contained no claim of copyright infringement.

163. Id. T 50-55. UNIX® is a registered trademark of The Open Group. See The Open Group, About The Open Group: Boundaryless Information Flow Through Interoperability, at http://www.opengroup.org/tm-guidelines.htm (last visited Feb. 16, 2005).

164. SCO Complaint, supra note 162 , शी 50-55, 92-98.

165. It is impossible to appreciate how incongruous some of SCO's claims are without understanding its corporate history. The Santa Cruz Operation (SCO) was a UNIX company, started in 1979, that was acquired by Caldera in 2001, which was a GNU/Linux company founded in 1994. The name "The SCO Group" was adopted under a new CEO in 2002. As just one example of how these changes reduced institutional memory, SCO's complaint alleged that the Linux kernel could never have developed into an enterprise-class product without IBM providing hardware and the accompanying know-how. However, the first shared multiprocessor (SMP) version of the Linux kernel was written by Alan Cox with hardware donated by Caldera. See Linux SMP, at http:// web.archive.org/web/20040202090712/http://www.linux.org.uk/SMP/title.html (last visited Mar. 6, 2005) ("The initial port was made possible thanks to [Caldera logo image with alternate text 'Caldera']."). Additionally, at least one Caldera employee apparently made significant contributions to a now-disputed portion of the Linux kernel, the Journaling File System (JFS). Pamela Jones, Caldera Employee Was Key Linux Kernel Contributor, GROKLAW, July 18, 2003, at http://www.groklaw.net/article.php?story=128. While a full investigation of numerous similar points is not possible here, the story can be partially unraveled at Eric Raymond, OSI Position Paper on the SCO-vs. -IBM Complaint (May 25, 2004), at http://www.opensource.org/sco-vs-ibm.html, and The SCO Group, Company History of SCO, at http://www.caldera.com/company/history.html (last visited Mar. 6, 2005).

166. SCO Complaint, supra note 162, T 120. SCO later raised this amount to fifty billion dollars. Hiawatha Bray, SCO Revokes IBM's Rights to UNLX Code Threatens the Future of Linux as Firm Seeks $\$ 50 B$ in Damages, BOSTON GLOBE, June 17, 2003, at D1.

167. SCO announced Boies' retention in January, see Stephen Shankland, SCO Casts Wider Net for Infringers, CNET NEWS.COM, Jan. 22, 2003, at http://news.com.com/2102 1001_3-981569.html?tag=st.util.print, but may have hired him even earlier, see Steven J. Vaughan-Nichols, SCO Linux/Unix Licensing Nonsense, Practical Technology (Jan. 16, 2003), at http://www.practical-tech.com/business/b01162003.htm ("[U]nnamed sources 
an unfavorable light, such as "Prior to IBM's involvement, Linux was the software equivalent of a bicycle. UNIX was the software equivalent of a luxury car."; 168 and (4) SCO's CEO, Darl McBride, offered numerous interviews and held a teleconference for the press the day after the suit was filed. ${ }^{169}$

SCO asserted that it was "the present owner of both UNIX and SCO/UNIX software" and that it had the right to revoke IBM's license to use or sublicense its UNIX systems, both claims that Novell, Inc. would soon contest. ${ }^{170} \mathrm{SCO}$ initially assured its own GNU/Linux customers that the suit was purely a contractual dispute with IBM, and CEO Darl McBride stated that, "This case is not about the Linux community or us going after them." "171 However, within a few months, SCO, analogized its situation to that of the music industry and sent letters to 1,500 corporate GNU/Linux users explaining its belief that "Linux infringes on our UNIX intellectual property and other rights" gressively protect and enforce these rights."173 While many were skeptical of SCO's claims from the beginning, ${ }^{174}$ conspiracy theorists felt vindicated

... said that David Boies, of DOJ vs. Microsoft fame, had been hired by SCO to represent the company.").

168. SCO Complaint, supra note 162, ๆ 84.

169. SCO Files Lawsuit Against IBM, PR Newswire, Mar. 7, 2003.

170. SCO Complaint, supra note 162 , ๆ $2,18,44,60,105,117$. For Novell's claims to own UNIX copyrights and the right to veto SCO's revocations of IBM's rights, see Novell, Novell's Unique Legal Rights, at http://www.novell.com/licensing/indemnity/legal.html (last visited Mar. 6, 2005); Letters between Joseph A. LaSala; Jr., Senior Vice President of Novell, Inc. and Ryan E. Tibbitts, General Counsel of SCO, can be obtained at $\mathrm{http}: / / \mathrm{www}$.novell.com/licensing/indemnity/zip/correspondence.zip. Of particular interest are the letters dated June 9, 2003; June 12, 2003; August 4, 2003; December 23, 2003; and February 11, 2004. These letters assert Novell's ultimate authority over SCO's UNIX licenses and assert ownership of UNIX copyrights.

171. Peter Galli, SCO: IBM Suit Not About Linux, EWEek, Mar. 7, 2003, at http://www.eweek.com/print_article2/0,2533,a $=38189,00$.asp.

172. Peter Galli, SCO Warns Linux Users of Legal Liability, EWEEK, May 14, 2003, at http://www.eweek.com/print_article2/0,2533,a=41623,00.asp; see Letter from Darl McBride, President and CEO, The SCO Group, to Lucio A. Noto, Audit Committee Chair, IBM 2 (May 12, 2003) [hereinafter McBride Letter], available at http://www. groklaw.net/pdf/Doc-41-I.pdf. This letter was sent to 1500 corporate GNU/Linux users. See Galli, supra note 171, at 2.

173. McBride Letter, supra note 172, at 2.

174. Members of the free software community, organized by Groklaw.net, collaboratively wrote an open letter to SCO CEO, Darl McBride. While the letter appeared after the announcement of Microsoft's purchase of a UNIX license, it summarized the reactions to the SCO suit by many in the community both before and after that announcement. Letter from members of The Open Source/Free Software Community at Groklaw to Darl McBride, CEO, The SCO Group (Sept. 18, 2003), available at http://www. 
when it was revealed that, just over two months after SCO filed suit against IBM, Microsoft bought a UNIX license from SCO for between $\$ 10-20$ million. ${ }^{175}$ Some speculated that this UNIX license was merely a means for Microsoft to pay for someone else to blunt the competition it was increasingly seeing from GNU/Linux. ${ }^{176}$

SCO's original complaint has been amended several times, and IBM's counterclaims stretch into the double digits. ${ }^{177}$ The case is still fought in the press as much as in court. ${ }^{178}$ However, this complex legal fight may yet yield a long-awaited U.S. ruling on the enforceability of the GPL.

\section{Will the GPL Be Tested in a U.S. Court?}

The possibility for a test of the GPL in the United States arose in August 2004 when IBM filed a motion for partial summary judgment as to one of its many counterclaims against SCO. ${ }^{179}$ The counterclaim asserted that SCO had violated the terms of the GPL in two ways. First, IBM alleged SCO violated the GPL by implementing its. SCOsource Licensing program in an attempt to. extract licensing fees from GNU/Linux users. IBM alleged that this was a violation of the GPL because it imposed an additional restriction on the rights of downstream users of software licensed under the GPL, which is forbidden by Section 6 . $^{180}$ Second, IBM

groklaw.net/staticpages/index.php?page $=20030923112622826$. For related research used in the preparation of that letter, see Pamela Jones and the Groklaw Team, Digging for Truth, INQUIRERE, Sept. 19, 2003, at http://www.theinquirer.net/?article=11649.

175. Dan Richman, Microsoft, SCO Reach Deal on UNIX, SEATTLE POSTINTELLIGENCER, May 20, 2003, at C2.

176. Timothy Prickett Morgan, Microsoft Licenses Unix from SCO Group, IT JUNGLE, May 21, 2003, at http://www.itjungle.com/mid/mid052103-story03.html; see Peter Galli, Microsoft Covers Back With SCO Unix License; EWEEK, May 26, 2003 ("A Unix/Linux programmer in Boston also questioned whether Microsoft really needed another Unix license given that it held one of the original ATT Unix licenses, the same one Sun Microsystems Inc. has. [A Microsoft spokeswoman] declined to comment."), at http://www.eweek.com/print_article2/0,2533,a=42354,00.asp.

177. SCO v. IBM Legal Documents With Exhibits, Groklaw, available at http:// www.groklaw.net/staticpages/index.php?page $=20041008201501977 \#$ scovibm (last visited Feb. 16, 2005).

178. A LexisNexis news search for "SCO and IBM" produced 1,082 results for 2004.

179. Redacted Memorandum in Support of IBM's Motion For Partial Summary Judgment on its Counterclaim for Copyright Infringement (Eighth Counterclaim), The SCO Group, Inc. v. Int'l Bus. Machs. Corp. (D. Utah 2004) (No. 2:03CV-0294 DAK), [hereinafter IBM Summary Judgment Motion], available at http://www.utd.uscourts.gov /reports/ibm/00000231.pdf.

180. The SCOsource program, if it purports to require licensing fees for alreadydistributed GPL-covered code, is a violation of the GPL's Sections 4 and 6 , because an attempt to impose a different license with an accompanying licensing fee on third parties 
argued that SCO was distributing sixteen of IBM's own contributions to the Linux kernel, while simultaneously rejecting the GPL license that covers them. This is analogous to the successful argument Harald Welte and the netfilter/iptables project made in Munich. ${ }^{18}$ IBM essentially argued, that if SCO distributes IBM's code, then SCO has to accept IBM's license. ${ }^{182}$ If SCO has repudiated the GPL, then Sections 4 and 5 indicate that SCO has no right to distribute the GPL-covered code.

IBM was able to bring this enforcement action because it holds copyrights in over 783,000 lines of code in the Linux kernel and licenses them under the GPL. ${ }^{183}$ Sixteen such contributions are specified in IBM's motion. ${ }^{184}$ SCO appeared to repudiate the GPL license, in several of SCO's answers to IBM's counterclaims, ${ }^{185}$ and SCO's CEO even publicly claimed, in an open letter on the SCO website, that the GPL was an unconstitutional violation of U.S. copyright and patent laws, ${ }^{186}$ despite the fact that SCO continued to distribute code licensed under the GPL.

who have already received GPL-covered code would be an impermissible further restriction on those recipients' exercise of the rights granted to them by the GPL. Thus, SCO must be careful to insist that it is only charging for its own software, not covered by the GPL, which would be permissible.

181. See supra Part IV.B.

182. Notably, IBM could lose this motion and it would not necessarily mean that the GPL is not enforceable. If SCO could show that there remain material facts in dispute, partial summary judgment would be premature.

183. IBM Summary Judgment Motion, supra note 179, at 6 .

184. Id. at 3-5.

185. SCO's Answer to IBM's Amended Counterclaims . Tा 23, 25, 27, 71, 73, 108, 120, 122, The SCO Group, Inc. v. Int'l Bus. Machs. Corp. (D. Utah 2004) (No. 03-CV0294) [hereinafter SCO's Answer] (essentially repeating the phrase "denies the enforceability of the GPL"), available at http://www.groklaw.net/pdf/AnswerAmendCC.10-2403.pdf; see id. at 16 (Sixth Affirmative Defense: "The General Public License ('GPL') is unenforceable, void and/or voidable, and IBM's claims based thereon, or related thereto are barred"); id. (Eighth Affirmative Defense: 'The GPL violates the U.S. Constitution, together with copyright antitrust and export control laws, and IBM's claims based thereon, or related thereto, are barred"). See also Side-by-Side Comparison of IBM Counterclaims and SCO Answer, Groklaw, Nov. 1, 2003, at http://www.groklaw.net/article. php?story=20031101060614944. SCO again alleged each of the above in its SCO's Amended Answer to IBM's Amended Counterclaims, The SCO Group, Inc. v. Int'l Bus. Machs. Corp. (D. Utah 2004) (No. 03-CV-0294), available at http://www.utd.uscourts. gov/reports/ibm/00000112.tif (last visited Feb. 16, 2005), and each of them yet again in SCO's Answer to IBM's Second Amended Counterclaims, The SCO Group, Inc. v. Int'1 Bus. Machs. Corp., (D. Utah 2004) (No. 03-CV-0294), available at http://www.utd.us courts.gov/reports/ibm/00000141.tif.

186. Open Letter from Darl McBride, CEO, The SCO Group (Dec. 4, 2003) [hereinafter McBride Open Letter], at http://www.caldera.com/copyright. The letter states: 


\section{SCO's Reply}

In response to IBM's motion for partial summary judgment, SCO's reply claimed that it had neither repudiated nor violated the GPL. ${ }^{187} \mathrm{SCO}$ stated that it was not charging licensing fees for GPL-covered code. ${ }^{188}$ Rather, SCO asserted that it was charging licensing fees for its UNIX code, which was allegedly inserted into GNU/Linux systems by IBM. ${ }^{189}$ SCO acknowledged that the bulk of the code in a GNU/Linux distribution is legitimately covered by the GPL, and SCO claimed it was not charging for that code. ${ }^{190}$ Instead, SCO asserted that it owned the copyright on some code in the Linux kernel, which Novell also claims as its own, ${ }^{191}$ and it is this code that SCO claimed to be entitled to charge fees under the SCOsource licenses.

SCO further asserted that, while it may have stated that the GPL was void and unenforceable in documents it filed with the court, those statements should not be held against it, because it is allowed to plead in the alternative. ${ }^{192}$ However, SCO's reply fails to address the statements closest to a repudiation of the GPL, the assertions made by its CEO, who pub-

SCO asserts that the GPL, under which Linux is distributed, violates the United States Constitution and the U.S. copyright and patent laws.....

[W] believe that responsible corporations throughout the IT industry have advocated use of the GPL without full analysis of its long-term detriment to our economy. We are confident that these corporations will ultimately reverse support for the GPL, and will pursue a more responsible direction.

$I d$. It is hard to imagine what more one could do to repudiate the GPL than to deny its enforceability and applicability dozens of times on three separate occasions, and then again in an open letter from one's CEO to claim it was an unconstitutional mistake. If SCO's actions did not amount to a repudiation of the GPL, then it may not be possible to repudiate the GPL, and it apparently acts as a license for even those who would refuse it.

187. Opposition to IBM's Motion for Partial Summary Judgment on its Counterclaim for Copyright Infringement (Eighth Counterclaim), at 1, 13, The SCO Group, Inc. v. Int'l Bus. Machs. Corp. (D. Utah 2004) (No. 2:03CV0294DAK) [hereinafter SCO Reply to Summary Judgment], available at http://www.utd.uscourts.gov/reports/ibm/00000342. pdf. Instead of "violate," SCO stated "breach the GPL" which assumes that the GPL is a contract. See supra note 27. But see sources cited supra note 64.

188. SCO's Reply to Summary Judgment, supra note 187, at 16.

189. Recall that Novell asserts that it owns the copyrights to the UNIX code that SCO claims to be licensing. See Novell, supra note 170.

190. SCO's Reply to Summary Judgment, supra note 187, at 15-17.

191. Although Novell does not assert that the code has been inappropriately placed into the Linux kernel.

192. Id. at 14-15; see FED. R. CIV. P. 8(e)(2). 
licly claimed that the GPL "violates the United States Constitution and the U.S. copyright and patent laws." 193

\section{Analysis of SCO's Reply}

Until further discovery is completed, at least two material facts in dispute appear to preclude IBM's success on the first prong of its argument related to licensing fees. However, IBM may prevail on its counterclaim of repudiation. SCO's claim that it is only charging for its own code is the only potential response to IBM's motion. Otherwise, if SCO acknowledged that it was charging royalties for GPL-covered code, it would be in violation of the GPL and would likely lose its license. In any case, SCO faces additional problems.

SCO's first problem is that the court may stop it from changing its story. First, SCO has been stating publicly that it is charging $\$ 699$ for "Linux," not "part of Linux," under a license it calls the "SCO Intellectual Property License for Linux." 194 The court might prevent SCO from claiming that it is merely charging buyers for a fraction of the kernel that it claims as its own. SCO's license fee appears to be a flat fee for an entire kernel or an entire Operating System. So the court could find that this is what it is. ${ }^{195}$ Secondly, Novell asserts that it owns the code in question. ${ }^{196}$ Therefore, SCO must prove (1) that it owns the code in question and (2) that the code it owns is improperly licensed under the GPL. Given the nature of a motion for summary judgment, it seems premature for the court to resolve this motion based upon the first prong of IBM's argument. ${ }^{197}$

193. See McBride Open Letter, supra note 186.

194. The SCO Group, SCO IP Licenses, at http://shop.sco.com/caldera/summary.jsp ?collection=Scosource (last visited Mar. 6, 2005) [hereinafter The SCO Group, SCO IP Licenses] ("SCO IP Paid Up License - 1-CPU - \$699.00."); The SCO Group, SCOsource, at http://www.sco.com/scosource/linuxlicense.html (last visited Mar. 6, 2005).

195. For comparison, Red Hat's Enterprise Linux ES Basic, which includes a year of support, costs half (\$349) of what SCO is charging, and RHEL ES Standard costs \$799, which includes Installation and Documentation Media (CDs), Printed Installation Guide, and faster phone service response time. See Red Hat, Inc., Red Hat Enterprise Linux ES, at http://www.redhat.com/apps/commerce/rhel/es/? (last visited Feb. 16, 2005). SCO's price of $\$ 699$ for its "SCO Intellectual Property License for Linux" is comparable then to what other GNU/Linux distributors charge for an entire operating system with a year of support. See The SCO Group, SCO IP Licenses, supra note 194.

196. See Novell, supra note 170.

197. The public and the author are operating without the benefit of redacted portions of these memoranda that could conceivably resolve some of these facts. However, the dispute with Novell over code ownership is unlikely to have been resolved by any redacted information in these proceedings, leaving at least one material fact in dispute. 
IBM's claim of repudiation is more problematic for SCO. SCO failed to even address or explain the public comments made by SCO's CEO that could appear to repudiate the license agreement. Because if a licensee has claimed publicly that the license offered "violates the United States Constitution and the U.S. copyright and patent laws," 198 then it would be reasonable for the licensor to believe that someone who holds such a view does not intend to be bound by, agree to, accept, or benefit from such a license. Such public statements also are not pleadings and should not fall under Federal Rules of Civil Procedure 8(e)(2). If SCO repudiated, then under contract law, according to Corbin, the injured party no longer has to perform under the contract and has a legal right to damages, a right which arises instantaneously with the repudiation. ${ }^{199}$ Moreover, Sections 4 and 5 of the GPL indicate that such repudiation "automatically" terminates the license. SCO nonetheless argued that the GPL does not indicate "when" the license would terminate and claimed that the only notice it received of such termination was from IBM's motion for partial summary judgment itself. $^{200}$ However, if the court gives the word "automatically" its plain meaning, this would seem to indicate that SCO's license terminated at the moment SCO's CEO publicly repudiated the GPL. Therefore, the vital question for the court to address is: what constitutes a repudiation of the GPL? ${ }^{201}$

\section{An Early Ruling}

On February 9, 2005, recognizing the benefit that further discovery could have on the outcome of these and other claims by the parties, the court denied without prejudice IBM's motion for partial summary judgment on its counterclaim to enforce the GPL. The court explicitly provided that IBM could renew or refile its motion once discovery is complete. ${ }^{202}$ he decision did not reach the merits because there had been no hearing on IBM's motion and the decision was issued more than two weeks before IBM's reply brief was due.

198. McBride, supra note 186.

199. 12 ARTHUR LINTON CORBIN, CORBIN ON CONTRACTS $\S 1105$ (2002).

200. SCO's Reply to Summary Judgment, supra note 187, at 24-26.

201. Answering this question may require an initial resolution of whether the GPL is a contract or a pure license. This would be necessary in order to find the appropriate guidance on the respective standards of contract and pure license repudiation. However, the very notion of a repudiation of a pure license seems irrational in most cases. Why repudiate a unilateral grant of permission for which one provided no consideration?

202. Memorandum Decision and Order at 16 , The SCO Group, Inc. v. Int'l Bus. Machs. Corp. (D. Utah 2005) (No. 2:03CV0294 DAK), available at http://www.utd. uscourts.gov/reports/ibm/00000398.pdf (last visited Feb. 16, 2005). 
However, in ruling on another motion, the court gave some indication of its estimation of the parties' positions. The court noted that SCO's reason for seeking dismissal or a stay of IBM's claim for declaratory judgment on the non-infringement and non-inducement counterclaim "transformed during the course of briefing its motion." ${ }^{203}$ The court felt SCO contradicted itself: "Notwithstanding SCO's puzzling denial in its briefing that it has not alleged a claim against IBM for copyright infringement arising out of its use, reproduction, or improvement of Linux, it clearly has alleged such a claim."204 The court also expressed displeasure at SCO's use of the press: "Indeed, in light of SCO's lawsuit against [another corporate GNU/Linux user] and SCO's public statements during the last two years, which have essentially invited this claim, it is incomprehensible that SCO seeks to postpone resolution of this claim."205 Finally, the court provided the best indication yet that this litigation will end favorably for IBM:

Viewed against the backdrop of SCO's plethora of public statements concerning IBM's and others' infringement of SCO's purported copyrights to the UNIX software, it is astonishing that SCO has not offered any competent evidence to create a disputed fact regarding whether IBM has infringed SCO's alleged copyrights through IBM's Linux activities. Further, SCO, in its briefing, chose to cavalierly ignore IBM's claims that SCO could not create a disputed fact regarding whether it even owned the relevant copyrights.

Nevertheless, despite the vast disparity between SCO's public accusations and its actual evidence- - or complete lack thereofand the resulting temptation to grant IBM's motion, the court has determined that it would be premature to grant summary judgment ..... ${ }^{206}$

Even though the court determined that it was necessary to complete discovery before ruling on any dispositive motions, the court sent a strong signal to SCO that the time for hard evidence has arrived, and that, without it, IBM can renew or refile its motions and expect success. ${ }^{207}$ If IBM chooses to renew or refile its motion to enforce the GPL, one thing seems certain: simply by looking to the facts and to the terms of the GPL to determine the outcome, the district court can do much to indicate that the GPL is a valid and enforceable license. No one seriously suspects that the court will find the GPL unconstitutional and violative of the copyright and

203. Id. at 3.

204. Id. at 4.

205. Id.

206. Id. at 10 .

207. Id. at 16 . 
patent laws, despite SCO CEO Darl McBride's claims. Indeed, IBM appears to be well on its way to making the same argument that succeeded for Harald Welte in Munich: "You refuse the only license terms offered, yet you distribute the code. This makes you an infringer."

\section{CONCLUSION}

The GPL grew out of Richard Stallman's fervent desire to provide freedom to software users and developers. It has been widely adopted by both those who share his vision for a more free society and by those who simply appreciate the practical benefits that software freedoms provide. Some challenges still face the free software community that grew up around the GPL: the proliferation of software patents could derail the progress made thus far, what constitutes a derivative work within software remains contested and somewhat unclear, and a firm court decision on the GPL's enforceability continues to be elusive. The past year saw greater recognition of the problems software patents pose to the free software community and some moves were made to address them. Additionally, the Munich court decision enforcing the GPL and the continuing success of private GPL enforcement has bolstered the legal certainty surrounding the GPL. Furthermore, SCO's dispute with IBM may yet provide a U.S. ruling on the GPL. Finally, a Version 3 of the GPL is in the works, ${ }^{208}$ and it also will likely address these issues while continuing to encourage software users and developers to share and share alike.

208. See Peter Galli, GPL 3 to Take on IP, Patents, EWEEk, Nov. 22, 2004, at http:/www.eweek.com/article2/0,1759,1730102,00.asp; Peter Galli, Rewriting GPL No Easy Task, EWEEK, Feb. 2, 2005, at http://www.eweek.com/article2/0,1759,1758752,00. asp; Stephen Shankland, Sprucing up Open Source's GPL Foundation, CNET NEWS.COM, Dec. 23, 2004, at http://news.zdnet.com/2102-3513_22-5501561.html?tag= printthis. 
BERKELEY TECHNOLOGY LAW JOURNAL 